\title{
Herbage nutritive value of binary- and multi-species swards relative to single-species swards in intensive silage systems
}

\author{
T. Moloney ${ }^{1,2}$, H. Sheridan², J. Grant ${ }^{3}$, E.G. O'Riordan ${ }^{1}$, P. O'Kiely ${ }^{1 \dagger}$
}

${ }^{1}$ Teagasc, Animal \& Grassland Research and Innovation Centre, Grange, Dunsany, Co. Meath, Ireland

${ }^{2}$ School of Agriculture and Food Science, University College Dublin, Dublin 4, Ireland

${ }^{3}$ Teagasc, Food Research Centre, Ashtown, Dublin 15, Ireland

Abstract

The nutritive value of sown binary- and multi-species grassland mixtures may differ from the values expected based on single-species swards of their constituent species. Field plots were established in a split-plot design to assess the nutritive value of binary- and multi-species mixtures compared to single-species swards of three grass species and red clover (RC) (Trifolium pratense L.) managed for intensive silage production. The nutritive value of grass-legume binary mixtures reflected the values of the constituent species grown on their own, and thus may be predicted from monoculture values. The relatively low digestibility (dry matter digestibility [DMD]) and crude protein (CP) content of the Italian ryegrass (Lolium multiflorum L.) sward compared to perennial ryegrass (Lolium perenne L.) and timothy (Phleum pratense L.) suggests that it may have a limited role in binary- or multi-species swards. Herbage nutritive value in the multi-species swards (Mix 1: perennial ryegrass, timothy, RC and white clover [Trifolium repens L.]; Mix 2: perennial ryegrass, timothy, RC, ribwort plantain [Plantago lanceolata $L$.] and chicory [Cichorium intybus L.]) appeared to be influenced more by the presence of legumes than herbs. Compared to perennial ryegrass, the multi-species swards had a slower rate of DMD decline prior to Cut 1, but subsequently had lower DMD values at the mid-season harvests. Both multi-species mixtures exhibited DMD, water-soluble carbohydrate (WSC) and CP values that would not have been predicted from their constituent species and thus need to be measured on herbage from field plots growing these mixtures.

Keywords

Agricultural grasslands $\bullet$ crude protein $\bullet$ dry matter digestibility $\bullet$ multi-species swards $\bullet$ nutritive value

\section{Introduction}

Sown grassland swards containing species of grasses, legumes and herbs can, if appropriately formulated and managed, produce greater and less variable yields than monocultures of their constituent species (Lüscher et al., 2008; Nyfeler et al., 2009; Finn et al., 2013). Much of the potential yield advantage of these multi-species swards is derived from factors such as biological $\mathrm{N}$ fixation by rhizobia in legume root nodules and functional differences between species which can facilitate increased light- and nutrient-use efficiency (Cardinale et al., 2007; Temperton et al., 2007).

Differences in chemical composition between the three functional groups grass, legume and herb, and also the corresponding differences between and within species of each functional group, would be expected to be manifested in indices of nutritive value such as dry matter digestibility (DMD) and crude protein (CP) content (Fraser \& Rowarth, 1996; Li \& Kemp, 2005; Brink et al., 2015). Thus, for example, grasses such as timothy (Phleum pratense L.) can have a greater DMD than Italian ryegrass (Lolium multiflorum L.) at the same date during the primary growth (King et al., 2012), while temperate legumes typically have a greater CP content than temperate grasses (Phelan et al., 2015). Herb species such as ribwort plantain (Plantago lanceolata L.) and chicory (Cichorium intybus L.) can have similar DMD to perennial ryegrass when in the vegetative growth stage and are also rich in minerals (Sanderson et al., 2003; Pirhofer-Walzl et al., 2011), while some legume and herb species have relatively high concentrations of condensed tannins which can have implications for animal performance (Barry \& McNabb, 1999). In addition, the rate of DMD decline as plants advance from vegetative through inflorescence growth stages is lower for legumes such as red clover (RC) (Trifolium pratense L.) and white clover (Trifolium repens L.) than for perennial ryegrass (Dewhurst et al., 2009) and this has significant implications 
for the timing of silage harvest. Differences in the temporal growth patterns and thus the timing of peak nutritive value of grasses, legumes and herbs (Sanderson, 2010) may also offer potential to extend the period in which high-quality homeproduced forage is available.

On many commercial farms the primary management strategy for increasing herbage yield is to apply inorganic fertiliser $\mathrm{N}$ while ensuring that soil fertility, that is, $\mathrm{pH}$ and contents of phosphorus $(P)$ and potassium $(K)$, is not limiting the herbage growth. Such applications of inorganic nitrogen $(N)$ can impact the herbage nutritive value, for example, directly by increasing the CP content in grass and herb species (Keating \& O'Kiely, 2000b; Martin et al., 2017) or indirectly by altering sward botanical composition (Hopkins et al., 1990; Sanderson, 2010).

This study is part of a larger project undertaken under a four-cut silage production regime, the yield and botanical composition components of which have been reported by Moloney et al. (2020). The objectives of this study were to quantify the effects on the herbage nutritive value of (1) three common temperate grass swards receiving inorganic $\mathrm{N}$ or grown in binary mixtures with $\mathrm{RC}$, (2) a perennial ryegrass sward compared to a perennial ryegrass/ RC binary mixture or to two multi-species swards, each grown with zero inorganic $\mathrm{N}$ input, and (3) the response of a perennial ryegrass sward compared with two multi-species mixtures to receiving increasing rates of inorganic $\mathrm{N}(0-360 \mathrm{~kg}$ $\mathrm{N} /$ ha per year). As the timing of the harvest of the primary growth of herbage can have an important impact on the nutritive value of both the first and second cuts for silage production (Gilliland et al., 1995), and as these impacts may differ with sward type, the effects of harvest schedule (specifically the timing of the primary growth harvest) were also investigated. The latter would also allow elucidation of the rates of change in chemical composition traits at the time of the first cut.

\section{Materials and methods}

\section{Field plots}

Details of the layout and management of field plots established in September 2012 have been reported by Moloney et al. (2020). Briefly, in each of four replicate blocks, treatments were allocated in a split-plot design. The main plots involved the primary growth harvest of a four cut per year schedule being on 12-13 May (Early), 26-27 May (Middle) or 9-10 June (Late). Cuts 2 and 3 were harvested 7 and 14 wk after their primary growth harvest, while Cut 4 for all treatments was on 10 and 24 November in successive years. The subplots involved 18 treatments differing in herbage species and inorganic $\mathrm{N}$ input (Table 1). Details of the species and varieties used have been reported by Moloney et al. (2020). During 2013 all plots were fertilised and harvested as per the two following experimental years (Years 1 and 2 of results), but no data recording took place. Inorganic $\mathrm{N}$ was applied as calcium ammonium nitrate (CAN; $275 \mathrm{~g} \mathrm{~N} / \mathrm{kg}$ ), with 0.333 , $0.278,0.222$ and 0.167 of the annual allocation being applied at the commencement of the growths that culminated in Cuts $1-4$, respectively. Herbage was harvested using a Haldrup forage plot harvester (J. Haldrup, Løgstør, Denmark) to an approximate stubble height of $6 \mathrm{~cm}$ before being chopped and sampled. Samples (ca. $2 \mathrm{~kg}$ ) were stored at $-18^{\circ} \mathrm{C}$ prior to chemical analysis. The plot management regime of Years 1 and 2 was maintained through 2016 (Year 3) when single samples of timothy, RC, white clover, ribwort plantain and chicory were obtained from either the Mix $1 / 120 \mathrm{~N}$ or Mix 2/120N plots in each replicate block at Cuts $1-3$ of the

Table 1: Sward types and the associated species included, their rates of seed sown and the rates of inorganic $\mathrm{N}$ applied

\begin{tabular}{|c|c|c|c|}
\hline Sward & Species included & Seed rate ${ }^{1}$ & $\mathbf{N}^{2}$ \\
\hline TIM/360N & Timothy & 15 & 360 \\
\hline IRG/360N & Italian ryegrass & 42 & 360 \\
\hline PRG/0-360N & Perennial ryegrass & 32 & $0,120,240,360$ \\
\hline $\mathrm{RC}$ & Red clover & 15 & 0 \\
\hline TIM/RC & Timothy, red clover & 6,9 & 0 \\
\hline IRG/RC & Italian ryegrass, red clover & $16.8,9$ & 0 \\
\hline $\mathrm{PRG} / \mathrm{RC}$ & Perennial ryegrass, red clover & $12.8,9$ & 0 \\
\hline Mix 1/0-360 & Timothy, perennial ryegrass, red clover, white clover & $3,6.4,5.25,3$ & $0,120,240,360$ \\
\hline Mix 2/0-360 & Timothy, perennial ryegrass, red clover, ribwort plantain, chicory & $3,6.4,5.25,1.5,0.63$ & $0,120,240,360$ \\
\hline
\end{tabular}

${ }^{1} \mathrm{~kg} \mathrm{seed} / \mathrm{ha}$ (values correspond in order with species in the preceding column).

${ }^{2}$ Inorganic N input (kg N/ha per year). 
Early, Middle and Late harvest schedules, and these were stored at $-18^{\circ} \mathrm{C}$ prior to chemical analysis. Sward botanical composition and prevailing meteorological conditions have previously been reported by Moloney et al. (2020).

Prior to each harvest during Years 1 and 2, the herbage growth stage was determined according to Moore et al. (1991) for grass and Ohlsson \& Wedin (1989) for RC. For white clover, ribwort plantain and chicory, a growth stage index was devised based on an adaptation of the index developed by Ohlsson \& Wedin (1989) for RC, for which the numeric values and the corresponding criteria are described in Table 2.

\section{Chemical analysis}

Herbage dry matter (DM) content was estimated following drying in a forced-air circulation oven at $98^{\circ} \mathrm{C}$ for $16 \mathrm{~h}$. Replicate samples dried at $60^{\circ} \mathrm{C}$ for $48 \mathrm{~h}$ were milled through a 1-mm aperture sieve (Wiley mill, $1 \mathrm{~mm}$ screen) and used for the determination of chemical composition. In vitro DMD was determined using the method of Tilley \& Terry (1963) with the modification that the final residue was isolated by filtration (Whatman GF/A $55 \mathrm{~mm}$, pore size $1.6 \mu \mathrm{m}$; Whatman International, Maidstone, UK) rather than by centrifugation. Water-soluble carbohydrate (WSC) content was measured using the anthrone method (Thomas, 1977) on an Autoanalyser 3 (Bran and Leubbe $\mathrm{GmbH}$, Norderstedt, Germany), while ash was determined by complete combustion in a muffle furnace at $550^{\circ} \mathrm{C}$ for $5 \mathrm{~h}$. The $\mathrm{CP}$ content $(\mathrm{N} \times 6.25)$ was determined using an LECO FP $428 \mathrm{~N}$ analyser (Leco Instruments, St. Joseph, MI, USA) based on method 990-03 of Association of Analytical Chemists (AOAC, 1990). The content of WSC was not measured in Cut 4 samples.

\section{Statistical analysis}

The 18 sub-plot treatments within the main plots (three levels of harvest schedule) of this split-plot design, which had four replicate blocks, had a number of subsets with factorial

Table 2: Modified growth stage index for white clover, ribwort plantain and chicory

\begin{tabular}{lc}
\hline Growth stage number & Description \\
\hline 1 & Vegetative \\
1.5 & Stem appearance \\
2 & Stem visible; early elongation \\
2.5 & Late elongation \\
3 & Early reproductive phase; buds visible \\
3.5 & Reproductive phase; flowers visible \\
4 & Late reproductive phase; seeds developing \\
5 & Seed pods visible \\
\hline
\end{tabular}

structure and associated controls. The nested model, or elaborate contrasts, required to incorporate the controls and the multiple factorial sets of treatments resulted in undue complexity and, to avoid this, the sub-plot treatments were arranged into three groups for statistical analysis. The treatment contrasts within these groups addressed the three objectives identified at the end of the Introduction, and this is the same approach as used by Moloney et al. (2020).

Group 1 used seven of the 18 sub-plot treatments (PRG/360N, IRG/360N, TIM/360N, PRG/RC, IRG/RC, TIM/RC and RC) to give a $(3 \times 2)+1$ arrangement, with the +1 (i.e. $R C$ ) being a control. A nested linear model was used to accommodate this structure. For Group 2 the four sub-plot treatments PRG/ON, PRG/RC, Mix 1/0N and Mix 2/0N formed a simple four treatment contrast and in Group 3, 12 of the 18 sub-plot treatments (PRG/0-360N, Mix 1/0-360N and Mix 2/0-360N) provided a $3 \times 4$ factorial arrangement.

All analyses of these groups incorporated year, replicate blocks and harvest schedule as the main plot factors. In the first instance, harvest schedule was included in the analyses as a factor and then, with equally spaced time intervals, the analyses were repeated with schedule included as a covariate in an analysis of covariance, to identify trends over time. All interactions were tested and, in the analysis of covariance, linear and quadratic terms and their interactions were included. A similar analysis of covariance was used for inorganic $\mathrm{N}$ application rates in Group 3.

Residuals from all analysis models were checked to ensure that the assumptions of the analyses were met. Contrasts between means were specified for significant effects in the analyses and allowance for multiplicity effects used Tukey's adjustments to $P$-values.

All data were analysed using the GLIMMIX and MIXED procedures of SAS 9.3 (SAS, 2013).

\section{Results}

The corresponding values for the Early and Late harvest schedules are presented in Appendix Tables A1 and A2.

Tables of mean values for each sward species $x$ inorganic $\mathrm{N}$ treatment within each level of harvest schedule, and of corresponding standard errors of the mean and $P$-values for the three groups of treatment contrasts, are presented for DMD (Tables 3 and 4), WSC (Tables 5 and 6) and CP (Tables 7 and 8). Appendix Tables A3 (means) and A4 (standard errors of the mean and $P$-values) provide DM content values and Appendix Tables A5 and A6 provide the corresponding values for ash.

The mean chemical composition of five individual herbage species at Cuts 1-3 of the multi-species swards is presented in Table 9. 
Table 3: Mean in vitro dry matter digestibility $(\mathrm{g} / \mathrm{kg})$ at each cut, for each harvest schedule and sward species $\times$ inorganic $\mathrm{N}$ treatment (averaged across years)

\begin{tabular}{|c|c|c|c|c|c|c|c|c|c|c|c|c|}
\hline Cut & & 1 & & & 2 & & & 3 & & & 4 & \\
\hline Schedule $^{1}$ & $E$ & $M$ & $\mathbf{L}$ & $E$ & $M$ & L & $E$ & $M$ & $\mathbf{L}$ & $E$ & $\mathbf{M}$ & $\mathbf{L}$ \\
\hline \multicolumn{13}{|l|}{ Sward $^{2}$} \\
\hline IRG/360N & 757 & 723 & 654 & 674 & 655 & 663 & 689 & 738 & 765 & 700 & 761 & 784 \\
\hline TIM/360N & 775 & 733 & 673 & 714 & 669 & 718 & 769 & 764 & 762 & 748 & 774 & 782 \\
\hline $\mathrm{RC}$ & 756 & 746 & 703 & 723 & 693 & 686 & 721 & 768 & 763 & 732 & 761 & 739 \\
\hline IRG/RC & 772 & 741 & 688 & 717 & 638 & 670 & 718 & 768 & 765 & 741 & 749 & 791 \\
\hline TIM/RC & 787 & 740 & 689 & 720 & 672 & 705 & 728 & 761 & 762 & 717 & 761 & 774 \\
\hline PRG/RC & 795 & 744 & 696 & 742 & 695 & 721 & 722 & 758 & 765 & 706 & 764 & 787 \\
\hline PRG/ON & 816 & 747 & 687 & 790 & 763 & 784 & 814 & 798 & 787 & 740 & 778 & 793 \\
\hline $\mathrm{PRG} / 120 \mathrm{~N}$ & 794 & 736 & 662 & 781 & 757 & 766 & 786 & 805 & 779 & 714 & 783 & 804 \\
\hline $\mathrm{PRG} / 240 \mathrm{~N}$ & 784 & 720 & 635 & 764 & 733 & 766 & 793 & 794 & 786 & 718 & 732 & 792 \\
\hline $\mathrm{PRG} / 360 \mathrm{~N}$ & 784 & 739 & 631 & 749 & 738 & 777 & 789 & 803 & 803 & 684 & 752 & 789 \\
\hline Mix $1 / 0 \mathrm{~N}$ & 796 & 752 & 684 & 739 & 719 & 734 & 745 & 783 & 795 & 744 & 767 & 784 \\
\hline Mix $1 / 120 \mathrm{~N}$ & 785 & 739 & 686 & 753 & 711 & 677 & 762 & 800 & 800 & 730 & 779 & 776 \\
\hline $\operatorname{Mix} 1 / 240 \mathrm{~N}$ & 767 & 728 & 688 & 736 & 697 & 736 & 762 & 788 & 793 & 735 & 744 & 808 \\
\hline Mix $1 / 360 \mathrm{~N}$ & 775 & 720 & 662 & 733 & 702 & 740 & 765 & 781 & 805 & 719 & 781 & 776 \\
\hline Mix $2 / 0 \mathrm{~N}$ & 776 & 736 & 705 & 722 & 692 & 701 & 725 & 766 & 782 & 767 & 758 & 761 \\
\hline $\operatorname{Mix} 2 / 120 \mathrm{~N}$ & 773 & 738 & 674 & 727 & 693 & 714 & 727 & 759 & 779 & 734 & 756 & 773 \\
\hline Mix $2 / 240 N$ & 782 & 722 & 658 & 716 & 701 & 729 & 739 & 776 & 787 & 725 & 757 & 770 \\
\hline Mix $2 / 360 N$ & 771 & 744 & 668 & 726 & 703 & 723 & 753 & 768 & 793 & 738 & 766 & 797 \\
\hline
\end{tabular}

${ }^{1}$ Harvest schedule: $\mathrm{E}=$ Early, $\mathrm{M}=$ Middle, $\mathrm{L}=$ Late.

${ }^{2}$ Sward species $\times$ inorganic $\mathrm{N}$ treatment.

Table 4: Standard errors of the mean (SEM) and $P$-values for in vitro dry matter digestibility $(\mathrm{g} / \mathrm{kg})$ at each cut, for each harvest schedule and sward species $\times$ inorganic $\mathrm{N}$ treatment (averaged across years)

\begin{tabular}{|c|c|c|c|c|c|c|c|c|c|c|c|}
\hline Group ${ }^{1}$ & & 1 & & & & 2 & & 3 & & & \\
\hline Effect & & Species $^{2}$ & Source $^{2}$ & $\begin{array}{l}\text { Species } \\
\times \text { Source }\end{array}$ & $\begin{array}{c}\text { Species } \\
\times \text { Source } \\
\times \text { Schedule }\end{array}$ & Species $^{3}$ & $\begin{array}{c}\text { Species } \\
\times \text { Schedule }\end{array}$ & Species $^{4}$ & $\mathrm{~N}$ rate & $\begin{array}{l}\text { Species } \\
\times N \text { rate }\end{array}$ & $\begin{array}{l}\text { Species } \\
\times N \text { rate } \\
\times \text { Schedule }\end{array}$ \\
\hline \multirow[t]{2}{*}{ Cut 1} & SEM & 4.7 & 4.4 & 5.5 & 9.4 & 7 & 12.1 & 4.6 & 4.8 & 6.2 & 10.5 \\
\hline & $P$ & 0.018 & $<0.001$ & 0.134 & 0.032 & 0.55 & 0.091 & 0.465 & $<0.001$ & 0.106 & 0.032 \\
\hline \multirow[t]{2}{*}{ Cut 2} & SEM & 3.5 & 3 & 4.5 & 7.8 & 4.6 & 8 & 3.6 & 4 & 6.9 & 11.6 \\
\hline & $P$ & $<0.001$ & 0.011 & $<0.001$ & 0.041 & $<0.001$ & 0.681 & $<0.001$ & 0.463 & 0.051 & 0.428 \\
\hline \multirow[t]{2}{*}{ Cut 3} & SEM & 5.3 & 4.8 & 6.5 & 11.3 & 7.1 & 11.9 & 3.4 & 3.8 & 6.1 & 10.2 \\
\hline & $P$ & $<0.001$ & 0.001 & $<0.001$ & 0.131 & $<0.001$ & 0.009 & $<0.001$ & 0.377 & 0.277 & 0.759 \\
\hline \multirow[t]{2}{*}{ Cut 4} & SEM & 6.1 & 5.4 & 7.8 & 0.2 & 7.3 & 13 & 5.2 & 5.7 & 9.2 & 15.5 \\
\hline & $P$ & 0.16 & 0.762 & 0.052 & 12.93 & 0.021 & 0.001 & 0.669 & 0.257 & 0.253 & 0.677 \\
\hline
\end{tabular}

${ }^{1}$ Group $1=$ PRG/360N, IRG/360N, TIM/360N, PRG/RC, IRG/RC, TIM/RC and RC (the SEMs for Species were calculated for the $3 \times 2$ interaction but were also used when comparing RC to any of the $3 \times 2$ treatments); Group $2=\mathrm{PRG} / \mathrm{ON}, \mathrm{PRG} / \mathrm{RC}, \mathrm{Mix} 1 / \mathrm{ON}$ and Mix $2 / 0 \mathrm{~N}$; Group $3=$ PRG/0-360N, Mix 1/0-360N and Mix 2/0-360N.

${ }^{2}$ Within Group 1, Species is IRG, PRG or TIM and Source is either grass $+360 \mathrm{~kg} \mathrm{~N} /$ ha per year or grass + red clover.

${ }^{3}$ Within Group 2, Species is PRG/0N, PRG/RC, Mix 1/0N and Mix 2/0N.

${ }^{4}$ Within Group 3, Species is PRG, Mix 1 and Mix 2. Schedule = Harvest schedule. 
Table 5: Mean water-soluble carbohydrate content (g/kg DM) at Cuts 1-3, for each harvest schedule and sward species $\times$ inorganic $\mathrm{N}$ treatment (averaged across years)

\begin{tabular}{|c|c|c|c|c|c|c|c|c|c|}
\hline Cut & & 1 & & & 2 & & & 3 & \\
\hline Schedule $^{1}$ & $E$ & $M$ & $\mathbf{L}$ & $E$ & $M$ & $\mathbf{L}$ & $E$ & $M$ & $\mathbf{L}$ \\
\hline \multicolumn{10}{|l|}{ Sward } \\
\hline IRG/360N & 231 & 179 & 141 & 124 & 138 & 143 & 135 & 120 & 130 \\
\hline TIM/360N & 80 & 63 & 73 & 52 & 70 & 75 & 69 & 56 & 60 \\
\hline $\mathrm{RC}$ & 83 & 61 & 67 & 56 & 73 & 79 & 71 & 80 & 57 \\
\hline IRG/RC & 263 & 196 & 162 & 121 & 153 & 151 & 130 & 93 & 99 \\
\hline TIM/RC & 95 & 79 & 77 & 67 & 77 & 86 & 67 & 66 & 52 \\
\hline PRG/RC & 158 & 115 & 100 & 67 & 84 & 103 & 69 & 67 & 68 \\
\hline PRG/ON & 248 & 197 & 119 & 178 & 186 & 172 & 151 & 132 & 157 \\
\hline $\mathrm{PRG} / 120 \mathrm{~N}$ & 207 & 168 & 121 & 187 & 194 & 160 & 175 & 174 & 159 \\
\hline PRG/240N & 173 & 130 & 102 & 156 & 135 & 120 & 153 & 148 & 137 \\
\hline PRG/360N & 149 & 138 & 114 & 106 & 109 & 104 & 120 & 110 & 121 \\
\hline Mix $1 / 0 \mathrm{~N}$ & 132 & 97 & 126 & 60 & 85 & 90 & 68 & 59 & 67 \\
\hline Mix $1 / 120 \mathrm{~N}$ & 137 & 109 & 116 & 92 & 98 & 79 & 85 & 77 & 79 \\
\hline Mix $1 / 240 \mathrm{~N}$ & 106 & 97 & 104 & 77 & 88 & 80 & 85 & 84 & 91 \\
\hline Mix $1 / 360 N$ & 102 & 98 & 111 & 71 & 74 & 73 & 74 & 72 & 83 \\
\hline $\operatorname{Mix} 2 / 0 \mathrm{~N}$ & 135 & 108 & 106 & 63 & 83 & 78 & 80 & 63 & 58 \\
\hline $\operatorname{Mix} 2 / 120 \mathrm{~N}$ & 130 & 94 & 114 & 73 & 91 & 81 & 74 & 78 & 81 \\
\hline Mix $2 / 240 \mathrm{~N}$ & 116 & 94 & 86 & 65 & 78 & 80 & 84 & 83 & 95 \\
\hline Mix $2 / 360 N$ & 103 & 83 & 86 & 70 & 74 & 73 & 76 & 70 & 76 \\
\hline
\end{tabular}

${ }^{1}$ See footnotes beneath Table 3.

Table 6: Standard errors of the mean (SEM) and $P$-values for water-soluble carbohydrate content (g/kg DM) at Cuts 1-3, for each harvest schedule and sward species $\times$ inorganic $\mathrm{N}$ treatment (averaged across years)

\begin{tabular}{|c|c|c|c|c|c|c|c|c|c|c|c|}
\hline Group $^{1}$ & & 1 & & & & 2 & & 3 & & & \\
\hline Effect & & Species & Source & $\begin{array}{l}\text { Species } \\
\times \text { Source }\end{array}$ & $\begin{array}{c}\text { Species } \\
\times \text { Source } \\
\times \text { Schedule }\end{array}$ & Species & $\begin{array}{c}\text { Species } \\
\times \text { Schedule }\end{array}$ & Species & $\mathrm{N}$ rate & $\begin{array}{l}\text { Species } \\
\times N \text { rate }\end{array}$ & $\begin{array}{l}\text { Species } \\
\times N \text { rate } \\
\times \text { Schedule }\end{array}$ \\
\hline \multirow[t]{2}{*}{ Cut 1} & SEM & 4.4 & 3.6 & 6.2 & 10.7 & 6.1 & 10.5 & 3.5 & 3.8 & 5.8 & 10.1 \\
\hline & $P$ & $<0.001$ & 0.093 & 0.032 & 0.854 & $<0.001$ & $<0.001$ & $<0.001$ & $<0.001$ & 0.003 & 0.069 \\
\hline \multirow[t]{2}{*}{ Cut 2} & SEM & 4.1 & 3.7 & 5.5 & 9.6 & 4.7 & 8.1 & 2.4 & 2.7 & 4.1 & 7 \\
\hline & $P$ & $<0.001$ & 0.784 & 0.006 & 0.487 & $<0.001$ & 0.177 & $<0.001$ & $<0.001$ & $<0.001$ & 0.44 \\
\hline \multirow[t]{2}{*}{ Cut 3} & SEM & 4.2 & 3.9 & 5.1 & 8.9 & 6.1 & 10.5 & 2.8 & 3 & 4.3 & 7.5 \\
\hline & $P$ & $<0.001$ & $<0.001$ & $<0.001$ & 0.449 & $<0.001$ & 0.597 & $<0.001$ & $<0.001$ & $<0.001$ & 0.194 \\
\hline
\end{tabular}

${ }^{1}$ See footnotes beneath Table 4.

Perennial ryegrass, Italian ryegrass and timothy receiving inorganic $N$ or grown with RC (PRG/360N, IRG/360N, TIM/360N, PRG/RC, IRG/RC, TIM/RC and RC)

Herbage DMD at Cut 1 was greater $(P<0.001)$ for grass grown with RC than with inorganic N (739 vs. $719 \mathrm{~g} / \mathrm{kg}$ ) (Tables 3 and 4). Digestibility declined when the harvest date was delayed
(778, 737 and $672 \mathrm{~g} / \mathrm{kg})$ but there was a lesser $(P<0.001)$ decline for grass/RC (785 to $691 \mathrm{~g} / \mathrm{kg}$ ) than grass/360N (772 to $652 \mathrm{~g} / \mathrm{kg}$ ), while delaying the $P R G / 360 \mathrm{~N}$ harvest date resulted in a greater $(P<0.05)$ DMD decline $(784$ to 631 $\mathrm{g} / \mathrm{kg}$ ) than for IRG/360N (757 to $654 \mathrm{~g} / \mathrm{kg}$ ) and TIM/360N (775 to $673 \mathrm{~g} / \mathrm{kg})$. Red clover had a greater $(P<0.05)$ DMD 
Table 7: Mean crude protein content ( $\mathrm{g} / \mathrm{kg} \mathrm{DM})$ at each cut, for each harvest schedule and sward species $\times$ inorganic $\mathrm{N}$ treatment (averaged across years)

\begin{tabular}{|c|c|c|c|c|c|c|c|c|c|c|c|c|}
\hline Cut & & 1 & & & 2 & & & 3 & & & 4 & \\
\hline Schedule $^{1}$ & $E$ & $M$ & $\mathbf{L}$ & $E$ & $M$ & L & $E$ & $M$ & L & $E$ & $M$ & $\mathbf{L}$ \\
\hline \multicolumn{13}{|l|}{ Sward } \\
\hline IRG/360N & 129 & 105 & 86 & 120 & 103 & 107 & 131 & 152 & 174 & 200 & 251 & 296 \\
\hline TIM/360N & 157 & 131 & 94 & 127 & 115 & 136 & 172 & 175 & 188 & 215 & 285 & 314 \\
\hline $\mathrm{RC}$ & 223 & 185 & 144 & 183 & 175 & 158 & 181 & 219 & 263 & 264 & 290 & 316 \\
\hline IRG/RC & 101 & 93 & 85 & 126 & 88 & 94 & 130 & 177 & 187 & 198 & 229 & 250 \\
\hline TIM/RC & 175 & 139 & 102 & 144 & 143 & 153 & 191 & 208 & 220 & 247 & 282 & 295 \\
\hline PRG/RC & 154 & 133 & 85 & 151 & 147 & 144 & 163 & 206 & 219 & 229 & 248 & 270 \\
\hline PRG/ON & 85 & 78 & 64 & 91 & 82 & 93 & 108 & 143 & 132 & 180 & 201 & 226 \\
\hline PRG/120N & 96 & 80 & 65 & 82 & 83 & 101 & 96 & 115 & 124 & 167 & 188 & 231 \\
\hline PRG/240N & 119 & 96 & 76 & 102 & 123 & 135 & 119 & 128 & 137 & 179 & 197 & 241 \\
\hline PRG/360N & 142 & 106 & 87 & 138 & 142 & 168 & 157 & 172 & 174 & 201 & 231 & 271 \\
\hline Mix $1 / 0 \mathrm{~N}$ & 156 & 126 & 97 & 167 & 147 & 152 & 183 & 209 & 207 & 252 & 272 & 290 \\
\hline Mix $1 / 120 \mathrm{~N}$ & 132 & 104 & 89 & 124 & 123 & 134 & 165 & 172 & 165 & 228 & 245 & 269 \\
\hline Mix $1 / 240 \mathrm{~N}$ & 148 & 104 & 97 & 140 & 120 & 138 & 161 & 160 & 169 & 214 & 236 & 269 \\
\hline Mix $1 / 360 N$ & 145 & 116 & 92 & 147 & 138 & 157 & 179 & 176 & 178 & 222 & 259 & 274 \\
\hline Mix $2 / 0 \mathrm{~N}$ & 156 & 120 & 90 & 145 & 143 & 149 & 171 & 188 & 198 & 211 & 234 & 255 \\
\hline $\operatorname{Mix} 2 / 120 \mathrm{~N}$ & 136 & 116 & 87 & 127 & 114 & 127 & 157 & 158 & 159 & 192 & 219 & 245 \\
\hline Mix $2 / 240 N$ & 145 & 110 & 92 & 125 & 124 & 134 & 149 & 157 & 151 & 196 & 224 & 266 \\
\hline Mix $2 / 360 \mathrm{~N}$ & 162 & 124 & 93 & 142 & 136 & 148 & 173 & 176 & 186 & 217 & 245 & 282 \\
\hline
\end{tabular}

${ }^{1}$ See footnotes beneath Table 3.

Table 8: Standard errors of the mean (SEM) and $P$-values for crude protein content $(\mathrm{g} / \mathrm{kg} \mathrm{DM})$ at each cut, for each harvest schedule and sward species $\times$ inorganic $\mathrm{N}$ treatment (averaged across years)

\begin{tabular}{|c|c|c|c|c|c|c|c|c|c|c|c|}
\hline Group $^{1}$ & & 1 & & & & 2 & & 3 & & & \\
\hline Effect & & Species & Source & $\begin{array}{l}\text { Species } \\
\times \text { Source }\end{array}$ & $\begin{array}{c}\text { Species } \\
\times \text { Source } \\
\times \text { Schedule }\end{array}$ & Species & $\begin{array}{c}\text { Species } \\
\times \text { Schedule }\end{array}$ & Species & $\mathrm{N}$ rate & $\begin{array}{l}\text { Species } \\
\times N \text { rate }\end{array}$ & $\begin{array}{l}\text { Species } \\
\times N \text { rate } \\
\times \text { Schedule }\end{array}$ \\
\hline \multirow[t]{2}{*}{ Cut 1} & SEM & 2.4 & 2 & 3.4 & 5.9 & 4.1 & 7.1 & 2.2 & 2.4 & 3.3 & 5.6 \\
\hline & $P$ & $<0.001$ & 0.253 & $<0.001$ & 0.033 & $<0.001$ & $<0.001$ & $<0.001$ & $<0.001$ & $<0.001$ & 0.124 \\
\hline \multirow[t]{2}{*}{ Cut 2} & SEM & 3.2 & 2.6 & 4.5 & 7.8 & 4.9 & 8.6 & 2.3 & 2.5 & 3.7 & 6.3 \\
\hline & $P$ & $<0.001$ & 0.328 & 0.006 & 0.316 & $<0.001$ & 0.799 & $<0.001$ & $<0.001$ & $<0.001$ & 0.435 \\
\hline \multirow[t]{2}{*}{ Cut 3} & SEM & 3.9 & 3.2 & 5.4 & 9.4 & 6.2 & 10.7 & 2.2 & 2.4 & 3.8 & 6.7 \\
\hline & $P$ & $<0.001$ & $<0.001$ & 0.247 & 0.819 & $<0.001$ & 0.599 & $<0.001$ & $<0.001$ & $<0.001$ & 0.701 \\
\hline \multirow[t]{2}{*}{ Cut 4} & SEM & 2.3 & 1.9 & 3 & 5.6 & 3.7 & 6.7 & 2.3 & 2.6 & 4.4 & 8.2 \\
\hline & $P$ & $<0.001$ & 0.511 & $<0.001$ & 0.36 & $<0.001$ & 0.998 & $<0.001$ & $<0.001$ & $<0.001$ & 0.998 \\
\hline
\end{tabular}

${ }^{1}$ See footnotes beneath Table 4.

than IRG/360N or PRG/360N (735 vs. 711 and $718 \mathrm{~g} / \mathrm{kg}) . \quad(700 \mathrm{~g} / \mathrm{kg})$; however, PRG/RC (719 g/kg) had a lower At Cut 2, PRG/360N $(754 \mathrm{~g} / \mathrm{kg})$ had a greater $(P<0.001) \quad(P<0.001)$ value than PRG/360N. The DMD of RC $(700 \mathrm{~g} / \mathrm{kg})$ DMD value than IRG/360N $(664 \mathrm{~g} / \mathrm{kg})$ and TIM/360N was greater $(P<0.01)$ than IRG/360N and IRG/RC $(675 \mathrm{~g} / \mathrm{kg})$ 
Table 9: Mean chemical composition of individual herbage species at Cuts 1-3 of multi-species swards, for each harvest schedule

\begin{tabular}{|c|c|c|c|c|c|c|c|c|c|c|c|c|c|c|c|c|}
\hline \multirow{2}{*}{$\begin{array}{l}\text { Species } \\
\text { Schedule }^{1}\end{array}$} & & \multicolumn{3}{|c|}{ Timothy } & \multicolumn{3}{|c|}{ Red clover } & \multicolumn{3}{|c|}{ White clover } & \multicolumn{3}{|c|}{ Ribwort plantain } & \multicolumn{3}{|c|}{ Chicory } \\
\hline & & $E$ & M & L & $E$ & $\mathbf{M}$ & L & $E$ & $M$ & $L$ & $E$ & $M$ & L & $E$ & $M$ & L \\
\hline & Cut & & & & & & & & & & & & & & & \\
\hline \multirow[t]{3}{*}{ DMD } & 1 & 827 & 765 & 700 & 833 & 831 & 739 & 848 & 839 & 812 & 787 & 730 & 690 & 863 & 876 & 811 \\
\hline & 2 & 764 & 771 & 776 & 742 & 735 & 681 & 760 & 742 & 764 & 604 & 641 & 631 & 777 & 792 & 713 \\
\hline & 3 & 781 & 778 & 746 & 774 & 761 & 799 & 807 & 817 & 821 & 681 & 710 & 745 & 825 & 826 & 831 \\
\hline \multirow[t]{3}{*}{ WSC } & 1 & 225 & 177 & 146 & 111 & 120 & 128 & 110 & 120 & 77 & 129 & 110 & 88 & 136 & 117 & 93 \\
\hline & 2 & 108 & 102 & 89 & 84 & 89 & 87 & 58 & 73 & 79 & 66 & 91 & 71 & 74 & 128 & 137 \\
\hline & 3 & 133 & 136 & 115 & 107 & 100 & 127 & 117 & 105 & 109 & 91 & 109 & 127 & 161 & 166 & 166 \\
\hline \multirow[t]{3}{*}{$\mathrm{CP}$} & 1 & 128 & 131 & 119 & 287 & 246 & 226 & 285 & 270 & 253 & 175 & 161 & 151 & 244 & 194 & 160 \\
\hline & 2 & 132 & 126 & 108 & 214 & 208 & 201 & 240 & 230 & 236 & 111 & 113 & 123 & 132 & 156 & 109 \\
\hline & 3 & 149 & 155 & 177 & 212 & 215 & 235 & 246 & 200 & 248 & 118 & 127 & 150 & 126 & 110 & 189 \\
\hline \multirow[t]{3}{*}{ DM } & 1 & 256 & 257 & 259 & 154 & 152 & 167 & 150 & 150 & 204 & 129 & 125 & 131 & 121 & 107 & 111 \\
\hline & 2 & 255 & 213 & 259 & 181 & 180 & 172 & 183 & 139 & 146 & 191 & 206 & 175 & 136 & 161 & 146 \\
\hline & 3 & 245 & 267 & 250 & 178 & 184 & 185 & 185 & 145 & 150 & 203 & 220 & 168 & 150 & 165 & 169 \\
\hline \multirow[t]{3}{*}{ Ash } & 1 & 60 & 71 & 61 & 91 & 87 & 96 & 89 & 85 & 89 & 114 & 99 & 118 & 107 & 99 & 112 \\
\hline & 2 & 75 & 62 & 72 & 99 & 89 & 87 & 88 & 87 & 90 & 97 & 108 & 87 & 108 & 108 & 103 \\
\hline & 3 & 80 & 82 & 84 & 94 & 95 & 90 & 89 & 91 & 87 & 92 & 94 & 107 & 120 & 121 & 111 \\
\hline
\end{tabular}

${ }^{1}$ Harvest schedule: $\mathrm{E}=$ Early, $\mathrm{M}=$ Middle and $\mathrm{L}=$ Late. $\mathrm{DMD}=$ Dry matter digestibility $(\mathrm{g} / \mathrm{kg}), \mathrm{WSC}=$ water-soluble carbohydrates $(\mathrm{g} / \mathrm{kg} \mathrm{DM})$, ash (g/kg DM), CP = crude protein ( $/ \mathrm{kg} D M)$.

but less $(P<0.001)$ than PRG/360N. Herbage harvested at the Early $(719 \mathrm{~g} / \mathrm{kg})$ and Late $(709 \mathrm{~g} / \mathrm{kg})$ schedules had greater $(P<0.001)$ values than that harvested at the Middle harvest schedule $(678 \mathrm{~g} / \mathrm{kg})$. At Cut 3, PRG/360N $(798 \mathrm{~g} / \mathrm{kg})$ had a greater $(P<0.001)$ DMD value than IRG/360N $(731 \mathrm{~g} / \mathrm{kg})$ and $\mathrm{TIM} / 360 \mathrm{~N}(765 \mathrm{~g} / \mathrm{kg})$; however, when grasses were grown with RC, there was no difference in values. Herbage DMD increased $(P<0.05)$ when Cut 1 had been harvested later $(736,765$ and $770 \mathrm{~g} / \mathrm{kg})$. RC $(751 \mathrm{~g} / \mathrm{kg})$ was lower $(P<0.001)$ than $\mathrm{PRG} / 360 \mathrm{~N}$ but greater $(P<0.05)$ than IRG/360N $(731 \mathrm{~g} / \mathrm{kg})$. At Cut 4 the Early harvest schedule had the lowest $(P<0.001)$ value $(716 \mathrm{vs.} 760$ and $784 \mathrm{~g} / \mathrm{kg})$ while RC did not differ $(P>0.05)$ from the other sward species treatments.

At Cuts 1 and 2 but not Cut 3, IRG/360N (184 and $135 \mathrm{~g} / \mathrm{kg}$ $\mathrm{DM} ; 128 \mathrm{~g} / \mathrm{kg} \mathrm{DM})$ had a greater $(P<0.001)$ WSC content than PRG/360N (134 and $106 \mathrm{~g} / \mathrm{kg} \mathrm{DM} ; 117 \mathrm{~g} / \mathrm{kg}$ DM) but these were in turn greater $(P<0.001)$ than TIM/360N $(72,65$ and $62 \mathrm{~g} / \mathrm{kg}$ DM) (Tables 5 and 6 ). Delaying the harvest date from the Early to the Late schedules at Cut 1 reduced $(P<0.001)$ the herbage WSC in swards containing Italian (247 to $151 \mathrm{~g} / \mathrm{kg}$ $\mathrm{DM}$ ) and perennial (154 to $107 \mathrm{~g} / \mathrm{kg} \mathrm{DM}$ ) ryegrasses but not timothy, while at Cut 2 the Late schedule had a greater $(P<0.05)$ value compared to the Early schedule. At Cuts $1-3$, the WSC content of RC did not differ $(P>0.05)$ from that of
TIM/360N but was less $(P<0.001)$ than that of IRG/360N and PRG/360N.

At Cut 1, CP contents for the Early and Middle harvest schedules were greater $(P<0.001)$ for swards containing timothy (166 and $135 \mathrm{~g} / \mathrm{kg} \mathrm{DM}$ ) than perennial ryegrass (148 and $119 \mathrm{~g} / \mathrm{kg} \mathrm{DM})$ which in turn were greater $(P<0.001)$ than swards with Italian ryegrass (115 and $99 \mathrm{~g} / \mathrm{kg} D M$ ) (Tables 7 and 8). Furthermore, PRG/RC (124 g/kg DM) and TIM/RC $(138 \mathrm{~g} / \mathrm{kg} \mathrm{DM})$ had greater $(P<0.05)$ values than $\mathrm{PRG} / 360 \mathrm{~N}$ (112 g/kg DM) and TIM/360N (127 g/kg DM) while the opposite effect was observed for Italian ryegrass (93 and $107 \mathrm{~g} / \mathrm{kg} \mathrm{DM}$ ). Delaying the harvest date reduced $(P<0.001)$ the CP content with a greater reduction for swards containing perennial ryegrass (148 to $86 \mathrm{~g} / \mathrm{kg} \mathrm{DM}$ ) and timothy (166 to $98 \mathrm{~g} / \mathrm{kg} \mathrm{DM}$ ) than Italian ryegrass (115 to $85 \mathrm{~g} / \mathrm{kg} \mathrm{DM})$. The CP content at Cut 2 was greater $(P<0.01)$ for PRG $/ 360 \mathrm{~N}(149 \mathrm{~g} / \mathrm{kg}$ $D M)$ than $T I M / 360 \mathrm{~N}(126 \mathrm{~g} / \mathrm{kg} \mathrm{DM})$ which was greater than IRG/360N (110 g/kg DM); however, there was no difference $(P>0.05)$ between PRG/RC and TIM/RC. At Cut 3, swards containing Italian ryegrass had the lowest $(P<0.001) \mathrm{CP}$ contents, grass $/ 360 \mathrm{~N}(166 \mathrm{~g} / \mathrm{kg} \mathrm{DM})$ had lower $(P<0.001)$ values than grass/RC $(189 \mathrm{~g} / \mathrm{kg} \mathrm{DM})$ and the Early harvest schedule $(157 \mathrm{~g} / \mathrm{kg} \mathrm{DM})$ had lower $(P<0.001)$ values than the Middle (182 $\mathrm{g} / \mathrm{kg} \mathrm{DM})$ or Late $(194 \mathrm{~g} / \mathrm{kg} D M)$ schedules. For Cut 4 , swards containing timothy had the greatest $(P<0.001)$ 
values, while the Early harvest schedule $(215 \mathrm{~g} / \mathrm{kg} \mathrm{DM})$ had the lowest $(P<0.001)$ and the Late schedule $(283 \mathrm{~g} / \mathrm{kg} \mathrm{DM})$ the greatest $(P<0.001)$ values. The $\mathrm{CP}$ values at each cut were greater $(P<0.001)$ for RC than any of the grass monocultures.

Perennial ryegrass versus binary- and multi-species mixtures at ON (PRG/ON, PRG/RC, Mix 1/ON and Mix 2/ON)

Delaying the Cut 1 harvesting date reduced $(P<0.001)$ herbage DMD (796, 745 and $693 \mathrm{~g} / \mathrm{kg})$, while there was no difference $(P>0.05)$ in DMD between the four sward species treatments. At Cut 2, PRG $/ 0 \mathrm{~N}(780 \mathrm{~g} / \mathrm{kg})$ had the greatest $(P<0.001)$ DMD and Mix 1/0N $(731 \mathrm{~g} / \mathrm{kg})$ was greater $(P<0.01)$ than Mix $2 / 0 \mathrm{~N}(705 \mathrm{~g} / \mathrm{kg})$, while the Middle harvest schedule $(717 \mathrm{~g} / \mathrm{kg})$ resulted in a lower $(P<0.001)$ DMD than the Early $(748 \mathrm{~g} / \mathrm{kg})$ or Late $(735 \mathrm{~g} / \mathrm{kg})$ schedules. At Cut 3 , PRG/ON $(815 \mathrm{~g} / \mathrm{kg})$ had a greater $(P<0.01)$ DMD than all other sward species treatments $(722-745 \mathrm{~g} / \mathrm{kg})$ in the Early harvest schedule. When harvested in the Middle schedule, only PRG/RC $(758 \mathrm{~g} / \mathrm{kg})$ and Mix 2/0N $(765 \mathrm{~g} / \mathrm{kg})$ were less than PRG/0N $(798 \mathrm{~g} / \mathrm{kg})$, and there was no difference $(P>0.05)$ between the sward species treatments in the Late schedule. At Cut 4, PRG/0N $(771 \mathrm{~g} / \mathrm{kg})$ was greater $(P<0.05)$ than $P R G / R C(752 \mathrm{~g} / \mathrm{kg})$, while the Early harvest schedule $(740 \mathrm{~g} / \mathrm{kg})$ gave lower $(P<0.01)$ values than the two later schedules $(766$ and $780 \mathrm{~g} / \mathrm{kg})$.

At Cut $1, \mathrm{PRG} / 0 \mathrm{~N}$ had the greatest $(P<0.001)$ WSC content only at the Early (248 vs. $132-158 \mathrm{~g} / \mathrm{kg} \mathrm{DM}$ ) and Middle (197 vs. $97-115 \mathrm{~g} / \mathrm{kg}$ DM) harvest schedules (Tables 5 and 6 ). PRG/ON had the greatest $(P<0.001)$ WSC content at Cuts 2 (179 vs. $75-85 \mathrm{~g} / \mathrm{kg} \mathrm{DM}$ ) and 3 (147 vs. $65-68 \mathrm{~g} / \mathrm{kg} D M)$. The Early harvest schedule had the greatest $(P<0.001)$ values at Cut 1 (168 vs. $113-130 \mathrm{~g} / \mathrm{kg} \mathrm{DM})$ and the lowest $(P<0.05)$ values at Cut 2 (92 vs. $110-111 \mathrm{~g} / \mathrm{kg} \mathrm{DM}$ ).

Herbage CP content was lowest $(P<0.001)$ for PRG/ON at all cuts although at Cut 1 the magnitude of this effect declined as the harvest date was delayed (Tables 7 and 8 ). The Early harvest schedule had the greatest $(P<0.001)$ value and the Late schedule the lowest $(P<0.001)$ value at Cut $1(138 \mathrm{vs.} 84 \mathrm{~g} / \mathrm{kg}$ $D M)$, although the magnitude of this effect was quite small for PRG/ON. At Cut 3, CP was lowest $(P<0.05)$ for the Early harvest schedule, and at Cut 4 the values for Mix $2 / 0 \mathrm{~N}(233 \mathrm{~g} / \mathrm{kg}$ DM) were lower $(P<0.01)$ than for PRG $/ \mathrm{RC}(249 \mathrm{~g} / \mathrm{kg}$ DM) which in turn were lower $(P<0.001)$ than for Mix $1 / 0 \mathrm{~N}$ (272 g/kg DM).

Perennial ryegrass versus multi-species mixtures at increasing rates of inorganic N (PRG, Mix 1 and Mix 2 at $0,120,240$ and $360 \mathrm{~kg} \mathrm{~N} / \mathrm{ha}$ per year)

Herbage DMD was lower $(P<0.001)$ for Mix $1(723 \mathrm{~g} / \mathrm{kg})$ and Mix $2(729 \mathrm{~g} / \mathrm{kg})$ than perennial ryegrass $(764 \mathrm{~g} / \mathrm{kg})$ at Cut 2 , while at Cut 3 the same effect was significant only in the Early (758 and 736 vs. $796 \mathrm{~g} / \mathrm{kg}$ ) and Middle (788 and 767 vs. $800 \mathrm{~g} / \mathrm{kg}$ ) harvest schedules (Tables 3 and 4). At Cut 3 , a greater DMD for Mix 1 than Mix 2 also occurred only at the Early and Middle schedules. At Cut 1 , inorganic $\mathrm{N}$ application $(744-722 \mathrm{~g} / \mathrm{kg}$ for $0-360 \mathrm{~kg} \mathrm{~N} / \mathrm{ha})(P<0.001)$ and later harvesting dates $(784,735$ and $670 \mathrm{~g} / \mathrm{kg})(P<0.001)$ reduced DMD. For Cut 2, DMD was greatest $(P<0.01)$ for the Early $(745 \mathrm{~g} / \mathrm{kg})$ and Late $(737 \mathrm{~g} / \mathrm{kg})$ compared to the Middle $(717 \mathrm{~g} / \mathrm{kg})$ schedules, while for Cut 3 it was greatest $(P<0.01)$ for the Middle and Late schedules of the Mix 1 and Mix 2 swards. No effect of sward species treatment or rate of inorganic $\mathrm{N}$ applied occurred $(P>0.05)$ at Cut 4 , but values were lowest $(P<0.001)$ for the Early $(729 \mathrm{~g} / \mathrm{kg})$ and greatest $(P<0.05)$ for the Late $(785 \mathrm{~g} / \mathrm{kg})$ harvest schedules.

For Cut 1, WSC was greater $(P<0.001)$ for perennial ryegrass than Mix 1 and Mix 2 when harvested in the Early (194 vs. 120 and $121 \mathrm{~g} / \mathrm{kg} \mathrm{DM}$ ) and Middle (158 vs. 101 and $95 \mathrm{~g} / \mathrm{kg}$ DM) schedules but not in the Late schedule (Tables 5 and 6 ). The application of inorganic $\mathrm{N}$ reduced $(P<0.01)$ the WSC content and this effect was most pronounced in perennial ryegrass and in the Early harvest schedule. At Cuts 2 and 3 , perennial ryegrass had a greater $(P<0.001)$ WSC content than Mix 1 and Mix 2 (151 vs. 81 and $76 \mathrm{~g} / \mathrm{kg} \mathrm{DM,} 145$ vs. 77 and $76 \mathrm{~g} / \mathrm{kg} \mathrm{DM}$, respectively), although this effect diminished at increasing rates of inorganic $\mathrm{N}$ application.

Although the overall $\mathrm{CP}$ concentration at each cut was greater $(P<0.001)$ for both Mix 1 and Mix 2 than perennial ryegrass (Tables 7 and 8 ), the magnitude of this difference was reduced or eliminated $(P<0.001)$ by the application of inorganic $\mathrm{N}$ up to $360 \mathrm{~kg} \mathrm{~N} / \mathrm{ha}$ per year and the response to inorganic $\mathrm{N}$ was evident only with perennial ryegrass.

\section{Discussion}

Perennial ryegrass, Italian ryegrass and timothy receiving inorganic $N$ or grown with $R C$ (PRG/360N, IRG/360N, $T I M / 360 N, P R G / R C, I R G / R C, T I M / R C$ and $R C$ )

The generally lower DMD recorded at the first three cuts for IRG/360N compared to the other two grass species monocultures suggests that in order to produce silage of equal DMD to these other grasses, Italian ryegrass needs to be harvested after shorter growth intervals and therefore more frequent harvesting during the year is required compared to perennial ryegrass or timothy. When the latter strategy was employed by Keating \& O'Kiely (2000a), comparably high DMD values were obtained from both ryegrass species. Although the DMD of PRG/360N was lower than anticipated at Cut 1 , the similar values for PRG/360N and TIM/360N agree with King et al. (2012) while the clear advantage of $\mathrm{PRG} / 360 \mathrm{~N}$ over TIM/360N for the two mid-season cuts is likely explained by the more advanced growth stage observed 
with TIM/360N at Cuts 2 and 3 (Table 10; Appendix Tables A1 and $\mathrm{A} 2$ ).

While Clavin et al. (2017) noted a lower DMD for RC than for perennial ryegrass receiving inorganic $\mathrm{N}$ at each cut of a four harvest annual schedule, this was evident only with Cuts 2 and 3 in the current study. Therefore, the greater DMD value for RC than PRG/360N at Cut 1 supports the observation that the DMD from this cut of PRG/360N was lower than anticipated. This is further supported by King et al. (2012) who also reported that $\mathrm{RC}$ had a lower $\mathrm{DMD}$ in late May compared to perennial ryegrass receiving inorganic $\mathrm{N}$. The $\mathrm{DMD}$ of binary mixtures of $\mathrm{RC}$ with each of the three grass species sometimes reflected the ranking of their DMD values in monoculture and their relative contents in the binary mixture at each cut (Moloney et al., 2020). This agrees with the findings of Clavin et al. (2017) for RC and perennial ryegrass. However, in the case of IRG/RC, the DMD values were generally greater than the contribution of the relatively moderate proportion of RC would suggest. This outcome may be at least partly related to the observation that Italian ryegrass in IRG/RC was often at a less developed growth stage compared to that in IRG/360N (Table 10; Appendix Tables A1 and A2). The slower development of Italian ryegrass in IRG/RC may be a response to an inadequate supply of $\mathrm{N}$ due to the reduced $\mathrm{RC}$ content reported by Moloney et al. (2020).

The daily rate of decline in DMD of IRG/360N and TIM/360N between 12-13 May and 9-10 June, at 3.7 and $3.6 \mathrm{~g} / \mathrm{kg}$, respectively, was less than the daily rate for $P R G / 360 \mathrm{~N}$ in the current study $(5.5 \mathrm{~g} / \mathrm{kg})$ and also that reported by Gilliland et al. (1995). Furthermore, the inclusion of RC in a binary mixture with each grass species slowed the rate of DMD decline to one intermediate between the respective grass monocultures and the RC monoculture. The reduction in the rate of herbage DMD decline due to the inclusion of $R C$ in mixtures with grasses was previously noted by Dewhurst et al. (2009) and Peyraud et al. (2009).

The phenomenon demonstrated by Gilliland et al. (1995) that as the date of the first cut of the primary growth of a perennial ryegrass sward is delayed, the digestibility of its regrowth taken 6 wk later increases, was evident for the Early versus

Table 10: Mean growth stage indices for each herbage species from each sward species $\times$ inorganic $N$ treatment at Cuts 1-3 on the Middle harvest schedule, averaged across years

\begin{tabular}{|c|c|c|c|c|c|c|c|c|c|c|c|c|c|c|c|c|c|c|c|c|c|}
\hline \multirow{2}{*}{$\begin{array}{l}\text { Species } \\
\text { Cut }\end{array}$} & \multicolumn{3}{|c|}{ PRG $^{1}$} & \multicolumn{3}{|c|}{ IRG $^{1}$} & \multicolumn{3}{|c|}{ TIM $^{1}$} & \multicolumn{3}{|c|}{$\mathrm{RC}^{2}$} & \multicolumn{3}{|c|}{$w^{3}$} & \multicolumn{3}{|c|}{ PLANT $^{3}$} & \multicolumn{3}{|c|}{$\mathrm{CHIC}^{3}$} \\
\hline & 1 & 2 & 3 & 1 & 2 & 3 & 1 & 2 & 3 & 1 & 2 & 3 & 1 & 2 & 3 & 1 & 2 & 3 & 1 & 2 & 3 \\
\hline IRG/360N & & & & 2.8 & 3.4 & 2.7 & & & & & & & & & & & & & & & \\
\hline TIM/360N & & & & & & & 2.9 & 3.1 & 2.4 & & & & & & & & & & & & \\
\hline $\mathrm{RC}$ & & & & & & & & & & 2.8 & 5.0 & 4.2 & & & & & & & & & \\
\hline IRG/RC & & & & 2.8 & 3.2 & 2.6 & & & & 2.1 & 4.1 & 3.8 & & & & & & & & & \\
\hline TIM/RC & & & & & & & 2.5 & 2.8 & 2.4 & 2.6 & 4.7 & 4.0 & & & & & & & & & \\
\hline PRG/RC & 2.5 & 3.0 & 1.3 & & & & & & & 2.5 & 5.1 & 4.2 & & & & & & & & & \\
\hline PRG/ON & 2.4 & 2.1 & 1.5 & & & & & & & & & & & & & & & & & & \\
\hline PRG/120N & 2.7 & 2.7 & 1.5 & & & & & & & & & & & & & & & & & & \\
\hline PRG/240N & 2.7 & 2.9 & 1.5 & & & & & & & & & & & & & & & & & & \\
\hline $\mathrm{PRG} / 360 \mathrm{~N}$ & 2.7 & 3.0 & 1.5 & & & & & & & & & & & & & & & & & & \\
\hline Mix $1 / 0 \mathrm{~N}$ & 2.9 & 3.0 & 1.4 & & & & 2.5 & 2.8 & 1.7 & 2.3 & 4.8 & 4.4 & 1.0 & 2.3 & 3.5 & & & & & & \\
\hline Mix $1 / 120 \mathrm{~N}$ & 2.8 & 2.8 & 1.5 & & & & 2.5 & 3.0 & 2.1 & 1.9 & 4.7 & 4.3 & 1.0 & 2.3 & 3.5 & & & & & & \\
\hline Mix $1 / 240 \mathrm{~N}$ & 2.9 & 2.9 & 1.6 & & & & 2.7 & 3.1 & 2.3 & 2.2 & 4.4 & 4.6 & 1.0 & 2.3 & 3.5 & & & & & & \\
\hline Mix $1 / 360 \mathrm{~N}$ & 2.8 & 3.1 & 1.5 & & & & 2.5 & 3.0 & 2.1 & 2.2 & 3.9 & 3.4 & 1.0 & 2.3 & 2.3 & & & & & & \\
\hline Mix $2 / 0 \mathrm{~N}$ & 2.7 & 3.1 & 1.6 & & & & 2.5 & 3.0 & 1.7 & 2.3 & 4.7 & 4.5 & & & & 3.3 & 4.5 & 3.8 & 2.3 & 2.0 & 2.3 \\
\hline $\operatorname{Mix} 2 / 120 \mathrm{~N}$ & 2.8 & 2.9 & 1.7 & & & & 2.6 & 2.9 & 2.6 & 2.4 & 4.3 & 4.1 & & & & 3.3 & 4.5 & 3.8 & 2.8 & 2.5 & 2.0 \\
\hline Mix $2 / 240 N$ & 3.0 & 2.9 & 1.4 & & & & 2.6 & 3.1 & 2.2 & 2.3 & 4.6 & 3.8 & & & & 3.3 & 4.0 & 3.8 & 2.8 & 2.5 & 1.8 \\
\hline $\operatorname{Mix} 2 / 360 \mathrm{~N}$ & 3.0 & 3.1 & 1.6 & & & & 2.7 & 3.1 & 2.5 & 2.0 & 4.1 & 4.2 & & & & 3.3 & 4.0 & 3.3 & 2.8 & 2.5 & 1.3 \\
\hline
\end{tabular}

${ }^{1}$ Growth stage indices for perennial ryegrass (PRG), Italian ryegrass (IRG) and timothy (TIM) are from Moore et al. (1991). ${ }^{2}$ Indices for red clover (RC) are from Ohlsson \& Wedin (1989).

${ }^{3}$ Indices for white clover (WC), ribwort plantain (PLANT) and chicory (CHIC) are from Table 2. Indices for the Early and Late harvest schedules are in Appendix Tables A1 and A2, respectively. 
the Late harvest schedules of PRG/360N. However, no such response occurred for IRG/360N or TIM/360N, while for Cut 2 of $R C$ its $D M D$ declined in response to delaying the primary growth harvest. The latter in turn meant that the DMD of PRG/ $\mathrm{RC}$ also declined at Cut 2 in response to later harvesting of the primary growth.

The relative ranking for the WSC content of IRG/360N > PRG/360N > TIM/360N agrees with King et al. (2012), while RC, noted for its typically low WSC content, was similar to TIM/360N which also agrees with King et al. (2012). The magnitude by which the average WSC content of PRG/RC was lower than that of PRG/360N increased from Cut 1 through to Cut 3 , reflecting the increasing proportion and relatively low WSC content of RC in these swards. This negative effect of the elevated proportion of RC in mid-season agrees with findings previously described by Clavin et al. (2017). In contrast, the similar WSC contents in TIM/RC and TIM/360N reflect the similar WSC content of the monocultures of these species. This is supported by the findings of Hetta et al. (2003). In the case of Italian ryegrass, the absence of a consistent difference in WSC content between being grown with $\mathrm{RC}$ or inorganic $\mathrm{N}$ is likely due to the low proportion of $\mathrm{RC}$ in these swards. Furthermore, the low RC proportion led to the relatively high WSC content recorded for IRG/RC.

The generally lower CP content of IRG/360N, compared in particular to TIM/360N, and the consistently lower CP content of the three grass species monocultures receiving $360 \mathrm{~kg} \mathrm{~N} / \mathrm{ha}$ per year compared to RC agree with the findings of King et al. (2012). In the case of both perennial ryegrass and timothy, the trend for higher contents of $\mathrm{CP}$ for their mixtures with RC compared to the corresponding grass monocultures receiving inorganic $\mathrm{N}$ supports previous observations of Clavin et al. (2017) for perennial ryegrass and Hetta et al. (2003) for timothy. This trend suggests that in addition to the CP content of the binary mixtures being elevated by the proportion of $\mathrm{RC}$ present and its relatively high CP content, the atmospheric $\mathrm{N}$ fixed within the $\mathrm{RC}$ and made available to the companion grass increased the $\mathrm{CP}$ content of the latter compared to the grass monoculture when no inorganic $\mathrm{N}$ was applied, as was described by Gierus et al. (2012). In contrast to the outcomes for perennial ryegrass and timothy, the absence of a comparable response for the binary mixture of Italian ryegrass with $\mathrm{RC}$ reflects the effects of the relatively low proportion of $\mathrm{RC}$ in these swards (Moloney et al., 2020).

Perennial ryegrass versus binary- and multi-species mixtures at ON (PRG/ON, PRG/RC, Mix 1/ON and Mix 2/ON)

The relatively high DMD values at each cut of PRG/ON conform with results for perennial ryegrass grown without inorganic N fertiliser reported by Keating \& O'Kiely (2000b), Conaghan et al. (2012) and Clavin et al. (2017). The explanation for the tendency for the inclusion of RC with perennial ryegrass to reduce herbage $\mathrm{DMD}$, with the scale of this effect being particularly marked at Cuts 2 and 3 , resides with the consistently lower DMD values recorded for RC compared to PRG/ON and the relative proportions of these two species present at each cut (Moloney et al., 2020). Clavin et al. (2017) also repeatedly recorded lower DMD values for RC than perennial ryegrass under comparable conditions. However, as noted by Clavin et al. (2017), caution is required when interpreting such results as the relationship between in vitro digestibility and animal performance indices such as forage intake or animal growth rate can differ for grasses and legumes. This differential response may extend to herbs such as ribwort plantain and chicory.

The comparison between the DMD of PRG/RC and Mix $1 / 0 \mathrm{~N}$ is more complex than the preceding contrast as, even though both treatments are composed of grass and legume functional groups, there are possible additional but contrasting effects from the presence of timothy and white clover in Mix 1/0N. Furthermore, there is evidence that for some species at least, their DMD may be greater when in a multi-species sward than when in monoculture. For example, timothy in the multi-species swards generally had greater DMD values than when in monoculture (TIM/360N) and RC in these multi-species swards also recorded higher values compared to when in monoculture (RC) (Tables 3 and 9; note the values in Table 9 are from the following year). Finally, it is noteworthy that the proportion of the grass functional group present was generally slightly greater in Mix $1 / 0 \mathrm{~N}$ than in PRG/RC (37-86\% vs. $22-78 \%$ across cuts) and that for each cut of Mix 1/0N the proportions of both grasses were alike and of both clovers were alike. Thus, the outcome of these and possibly other factors was that even though herbage DMD values for both PRG/RC and Mix 1/ON were similar at Cut 1 they were $12-26 \mathrm{~g} / \mathrm{kg}$ greater for Mix $1 / 0 \mathrm{~N}$ at subsequent cuts. Some of the advantage to Mix $1 / 0 \mathrm{~N}$ is likely associated with the presence of white clover which in this study and as reported by Dewhurst et al. (2009) had a greater digestibility than RC. This is supported by Elgersma \& Schlepers (1997) who have shown a greater digestibility through the growing season for a mixed perennial ryegrass and white clover sward compared to a monoculture of the grass.

Compared to Mix 1/0N, Mix 2/0N involved the replacement of white clover by two species from a third functional group. In general, changes in the proportion of grass and RC present were modest (values for Mix 1/0N vs. Mix 2/0N across cuts were $37-5 \%$ vs. $35-74 \%$ grass and $7-33 \%$ vs. $9-41 \%$ RC) and the DMD values for chicory were generally at least as high as those for white clover (Table 9). Thus, the lower DMD values for Mix 2/0N than Mix 1/0N for the two mid-season cuts likely reflect the lower values recorded for ribwort plantain particularly at these two mid-season cuts. 
The differences between the four treatments in their daily rates of decline in DMD between 12-13 May and 9-10 June (4.6, $3.5,4.0$ and $2.5 \mathrm{~g} / \mathrm{kg}$ for PRG/0N, PRG/RC, Mix 1/0N and Mix $2 / 0 \mathrm{~N}$, respectively) are potentially of practical importance. However, the slowest rate of decline that occurred, with Mix $2 / 0 \mathrm{~N}$, is partially due to it having the lowest DMD among these treatments on 12-13 May.

The beneficial effect of a delayed first-cut harvest on the digestibility of a subsequent second cut described by Gilliland et al. (1995) for perennial ryegrass was not evident for any of the four treatments. Thus, it appears that this response for perennial ryegrass differs when it receives no inorganic $\mathrm{N}$ fertiliser (PRG/0N) compared to when it receives 360-400 $\mathrm{kg} \mathrm{N} / \mathrm{ha}$ annually (PRG/360N and Gilliland et al. (1995)). The numerical decline in Cut $2 \mathrm{DMD}$ for $\mathrm{PRG} / \mathrm{RC}$ and Mix $2 / 0 \mathrm{~N}$ compared to Mix 1/0N when managed under the Late compared to the Early harvest schedules likely relates to a beneficial effect of white clover in Mix 1/0N and negative impacts of $R C$ in $P R G / R C$ and of both $R C$ and chicory in Mix 2/0N (Table 9). Chicory has previously been shown to be capable of developing a woody stem quite rapidly in early summer (Li \& Kemp, 2005) and this would explain its reduced DMD.

Perennial ryegrass typically has a greater WSC content than most other grass and legume species commonly found in temperate permanent grassland (Wilson \& Collins, 1980; Dewhurst et al., 2009), and this relativity was reflected in the current study where PRG/ON had consistently greater values than the remaining three treatments. This outcome agrees with Ergon et al. (2017) when comparing perennial ryegrass with a four species grass and legume mixture. The values in Tables 5 and 9 suggest that the WSC advantage for PRG/ON emanated mainly from perennial ryegrasses' considerably greater WSC content than either legume or either herb present in the mixed species swards. However, they also suggest that the finding of Barry (1998) in which herbs such as chicory typically have a greater WSC content than legumes, specifically RC, was not consistently repeated when they were grown in multispecies swards in this study. In contrast to the relative values for perennial ryegrass and the legumes or herbs, timothy in the multi-species swards frequently had values much closer to $P R G / O N$ than their relative WSC contents when grown in monoculture and supplied with $360 \mathrm{~kg} \mathrm{~N} / \mathrm{ha}$ per year would indicate. This again suggests that aspects of the relative nutritive value of some species differ when they are grown in monoculture compared to when grown in multi-species swards.

The relatively low herbage CP content for PRG/ON, particularly at Cuts 1 and 2, is similar to the findings under comparable conditions by Keating \& O'Kiely (2000b), Conaghan et al. (2012) and Clavin et al. (2017). The marked increase in values consistently recorded for PRG/RC, Mix 1/0N and Mix
$2 / 0 \mathrm{~N}$, and the similarity of the values for these treatments within cuts, are likely due mainly to the direct effects of the high CP contents of both legumes as well as to an indirect effect of $\mathrm{N}$ fixed by the legumes increasing the $\mathrm{CP}$ content of the companion species. Thus, for example, the CP values for timothy within the multi-species swards (Table 9) are similar to those of TIM/360N and clearly greater than those of PRG/ON. It seems reasonable to assume that the CP content of both herbs will also have been enhanced by fixed $\mathrm{N}$ provided by the legumes, with particularly high values occurring in their primary growths. It is noteworthy that the $\mathrm{CP}$ content of $\mathrm{RC}$ within the multi-species swards was generally greater than when it was grown in monoculture. These examples are further evidence that the chemical composition of species grown in monoculture can differ from when grown with other species and that predicting the nutritive value of multi-species swards based on the proportion of each species in the observed mixture and the composition of each one when grown in monoculture can be problematic. The aforementioned findings are consistent with Sanderson (2010), Brink et al. (2015) and Ergon et al. (2017) who have shown that inclusion of forage legumes in multi-species swards with grasses and sometimes also herbs will elevate herbage CP content, occasionally in an apparently synergistic way.

\section{Perennial ryegrass versus multi-species mixtures at increasing rates of inorganic N (PRG, Mix 1 and Mix 2 at 0, 120, 240 and $360 \mathrm{~kg} \mathrm{~N} / \mathrm{ha}$ per year)}

Although the application of inorganic $\mathrm{N}$ to perennial ryegrass swards has been reported to have little effect on herbage DMD (Whitehead, 1995), both Cameron (1967) and Conaghan et al. (2012) have reported declines in DMD in response to inorganic $\mathrm{N}$, and the results of this study agree with the latter findings. The exact cause of this decline is not clear, although it may be associated with factors such as an accumulation of decaying herbage of reduced DMD or an increase in the proportion of stem present as DM yields increased in response to inorganic $N$ (Wilman, 2004), and to the decline in WSC content in response to inorganic N (Conaghan et al., 2012; Clavin et al., 2017).

An important side-effect of applying inorganic $\mathrm{N}$ to grassclover swards or to multi-species swards such as Mix 1 and Mix 2 is the alteration in their botanical composition, most commonly by reducing legume and increasing grass proportions (Hopkins, 1986; Harris \& Clark, 1996; Moloney et al., 2020). As sward botanical composition strongly influences herbage chemical composition (Michaud et al., 2012), the DMD response of the multi-species swards to inorganic $\mathrm{N}$ is at least partially explained by changes in sward botanical composition. Results from the current study, however, show little or no DMD decline for any cut of either multi-species sward in response to inorganic $\mathrm{N}$, except 
for Cut 1 of Mix 1 where there was a $25-\mathrm{g} / \mathrm{kg}$ decline when $360 \mathrm{~kg} \mathrm{~N} / \mathrm{ha}$ was applied annually. This general outcome occurred despite inorganic $\mathrm{N}$ application having been shown to reduce DMD in both perennial ryegrass (Conaghan et al., 2012) and timothy (Thorvaldsson \& Andersson, 1986) and that the proportions of both these grasses similarly increased in both mixtures with inorganic $\mathrm{N}$ application (Moloney et al., 2020). The latter increases were at the expense of both legumes in Mix 1 and the legume and both herbs in Mix 2. This raises the possibility that within Mix 1 and Mix 2 the mean DMD of the grass functional group may have been similar to the mean values of the legume or the legume plus herb functional groups.

There was no evidence in this study that applying increasing rates of inorganic $\mathrm{N}$ to perennial ryegrass, Mix 1 or Mix 2 had a clear-cut or substantive impact on the rates of decline in the DMD during their primary growth. In contrast, the beneficial response of Cut 2 perennial ryegrass herbage DMD to delaying the primary growth harvest that was first shown by Gilliland et al. (1995) occurred in this study only when perennial ryegrass received the highest rate of inorganic $\mathrm{N}$, which was a rate comparable to that used by Gilliland et al. (1995).

When considered at equivalent rates of inorganic $\mathrm{N}$ input some interactions of PRG, Mix 1 and Mix 2 with harvest schedule were evident, even if their magnitudes were sometimes relatively modest. Thus, at Cut 1 the slightly greater DMD for PRG than the multi-species swards on 12-13 May but its relatively lower value on 9-10 June suggest that this PRG would have a narrower timeframe than the multi-species swards in which to be harvested at optimal DMD. In contrast, at Cut 2, PRG had a superior DMD to the multi-species swards irrespective of the harvest schedule, but the DMD disadvantage for the multispecies swards at Cut 3 was associated mainly with the Early schedule for Mix 1 and with the Early and Middle schedules for Mix 2. Thus, for example, the Late harvest schedule might be a more appropriate strategy with Mix 2 in particular.

The general decline in the WSC content of perennial ryegrass in response to inorganic $\mathrm{N}$ application is similar to the findings of Keating \& O'Kiely (2000b), Conaghan et al. (2012) and Clavin et al. (2017). However, compared to the aforementioned relationship, the responses for Mix 1 and Mix 2 were greatly reduced or absent. In general in this study, species from the grass functional group had greater WSC contents than species from the legume or herb functional groups (Tables 5 and 9) and the effects on sward WSC content from the increasing proportion of grasses in Mix 1 and Mix 2 as inorganic $\mathrm{N}$ application increased may have been counter-balanced by a corresponding decline in grass WSC content, and possibly also in the WSC content of some of the legumes or herbs.

The increase in perennial ryegrass $\mathrm{CP}$ content in response to inorganic $\mathrm{N}$ agrees with previous studies by Keating \&
O'Kiely (2000b), Conaghan et al. (2012) and Clavin et al. (2017). In contrast, the response for both Mix 1 and Mix 2 to the same increases in inorganic $\mathrm{N}$ application generally showed an initial decline followed by a partial or complete recovery in $\mathrm{CP}$ content. The initial decline was likely due to the concurrent reduction in legume and increase in grass proportions (Elgersma et al., 2000; Brink et al., 2015), while the subsequent increase in $\mathrm{CP}$ content probably reflects the increase in $\mathrm{N}$ concentration in grass and herb species associated with elevated inputs of inorganic $\mathrm{N}$, as reported in the current study for perennial ryegrass and as described by Martin et al. (2017).

\section{Conclusion}

The relative nutritive values of perennial ryegrass, Italian ryegrass, timothy and RC grown in monoculture and in grasslegume binary mixtures suggest that the values for each binary mixture were determined mainly by the presence of RC. Thus, the nutritive value of such binary mixtures may be predicted from their monoculture nutritive values weighted for the relative proportions of each species present. In the case of Italian ryegrass, however, its relatively low DMD and $\mathrm{CP}$ content when managed in monoculture and subjected to similar harvest schedules as perennial ryegrass, timothy and RC suggest that it has a limited role in binary (or multispecies) mixtures as used in this study.

When managed without inorganic $\mathrm{N}$ application, the lower DMD for PRG/RC, Mix 1 and Mix 2 compared to PRG/ON, which was particularly evident for the two mid-season cuts, was counter-balanced by a corresponding increase in $\mathrm{CP}$ content. However, caution is required when interpreting DMD values for grasses versus legumes. Multi-species swards such as Mix 1 and Mix 2 may have a broader timeframe than perennial ryegrass in which to be harvested for first cut silage at optimal DMD. In a practical setting, however, the decision to harvest is also strongly influenced by factors such as herbage DM yield and weather conditions.

Although the herbage nutritive value in Mix 1 and Mix 2 was directly influenced by botanical composition, especially the contribution of their legume species, this alone does not explain all of the effects observed. Thus, for example, various species exhibited greater DMD, WSC or CP values when growing in multi-species swards compared to in monoculture. This phenomenon was in contrast to observations for binary mixtures. It is likely that the more complex growing conditions and interspecific interactions that occur in multi-species swards underpin these apparent differences. Consequently, predictions of the nutritive value of such multi-species swards based on the relative nutritive value of their component species in monoculture should be avoided. 
The effects of inorganic $\mathrm{N}$ application to perennial ryegrass of reducing DMD and WSC content but increasing CP content were as expected. The responses recorded with the two multispecies swards studied differed from this, mainly due to the associated changes in botanical composition.

\section{Acknowledgements}

The technical input of B. Weldon, the plot management operations by G. Costello and other Grange farm staff, the contributions of Grange Laboratories staff to chemical analyses and the advice of J. Finn, Teagasc, Johnstown Castle, Co. Wexford, Ireland in designing the two mixtures are acknowledged. All seeds were obtained from Goldcrop Ltd. (D. Barry; Springhill, Carrigtwohill, Co. Cork, Ireland), except Comer and Davinci (P. Conaghan, Teagasc, Oak Park, Co. Carlow, Ireland) and Puna (D. Murphy, Germinal Seeds, Horse \& Jockey, Thurles, Co. Tipperary, Ireland). Many thanks also to R. Fritch and S. Higgins for their technical input. Funding was provided by the Department of Agriculture, Food and the Marine through the Research Stimulus Fund (RSF 11/S/147).

\section{Declarations of interest}

None.

\section{References}

AOAC. 1990. "Official Methods of Analysis. First Supplement (1990) to the 15th edition, Method 990-03 15 edn". Association of Analytical Chemists, Arlington, VA, USA, pages 3-4.

Barry, T.N. 1998. The feeding value of chicory (Cichorium intybus) for ruminant livestock. The Journal of Agricultural Science 131: 251-257.

Barry, T.N. and McNabb, W.C. 1999. The implications of condensed tannins on the nutritive value of temperate forages fed to ruminants. British Journal of Nutrition 81: 263-272.

Brink, G.E., Sanderson, M.A. and Casler, M.D. 2015. Grass and legume effects on nutritive value of complex forage mixtures. Crop Science 55: 1329-1337.

Cameron, C. 1967. Intake and digestibility of nitrogen-fertilized grass hays by weathers. Canadian Journal of Animal Science 47: 123-125.

Cardinale, B.J., Wright, J.P., Cadotte, M.W., Carroll, I.T., Hector, A., Srivastava, D.S., Loreau, M. and Weis, J.J. 2007. Impacts of plant diversity on biomass production increase through time because of species complementarity. Proceedings of the National Academy of Sciences of the USA 104: 18123-18128.
Clavin, D., Crosson, P., Grant, J. and O'Kiely, P. 2017. Red clover for silage: management impacts on herbage yield, nutritive value, ensilability and persistence, and relativity to perennial ryegrass. Grass and Forage Science 72: 414-431.

Conaghan, P., O'Kiely, P., Halling, M.A., O'Mara, F.P. and Nesheim, L. 2012. Yield and quality response of perennial ryegrass selected for high concentration of water-soluble carbohydrate to nitrogen application rate. Crop Science 52: 2839-2851.

Dewhurst, R.J., Delaby, L., Moloney, A., Boland, T. and Lewis, E. 2009. Nutritive value of forage legumes used for grazing and silage. Irish Journal of Agricultural and Food Research 48: 167-187.

Elgersma, A. and Schlepers, H. 1997. Performance of white clover/ perennial ryegrass mixtures under cutting. Grass and Forage Science 52: 134-146.

Elgersma, A., Schlepers, H. and Nassiri, M. 2000. Interactions between perennial ryegrass and white clover under contrasting nitrogen availability: productivity, seasonal patterns of species composition, nitrogen yield, $\mathrm{N} 2$ fixation, $\mathrm{N}$ transfer and $\mathrm{N}$ recovery. Plant and Soil 221: 281-299.

Ergon, Å., Kirwan, L., Fystro, G., Bleken, M.A., Collins, R.P. and Rognli, O.A. 2017. Species interactions in a grassland mixture under low nitrogen fertilization and two cutting frequencies. II. Nutritional quality. Grass and Forage Science 72: 333-342.

Finn, J.A., Kirwan, L., Connolly, J., Sebastià, M.T., Helgadottir, A., Baadshaug, O.H., Bélanger, G., Black, A.D., Brophy, C., Collins, R.P., Cop, J., Dalmannsdottir, S., Delgado, I., Elgersma, A., Fothergill, M., Franklow-Lindberg, B.E., Ghesquiere, A., Golinska, B., Golinski, P., Grieu, P., Gustavsson, A.M., Hoglind, M., Huguenin-Elie, O., Jorrgensen, M., Kadziuliene, Z., Kurki, P., Llubra, R., Lunnan, T., Porqueddu, C., Suter, M., Thumm, U. and Lüscher, A. 2013. Ecosystem function enhanced by combining four functional types of plant species in intensively managed grassland mixtures: a 3-year continental-scale field experiment. Journal of Applied Ecology 50: 365-375.

Fraser, T.J. and Rowarth, J.S. 1996. "Published Legumes, Herbs or Grass for Lamb Performance?" New Zealand Grassland Association, Dunedin, New Zealand.

Gierus, M., Kleen, J., Loges, R. and Taube, F. 2012. Forage legume species determine the nutritional quality of binary mixtures with perennial ryegrass in the first production year. Animal Feed Science and Technology 172: 150-161.

Gilliland, T.J., Camlin, M.S. and Johnston, J. 1995. Effect of harvest date and cultivar maturity on perennial ryegrass (Lolium Perenne L.) yield and digestibility. Irish Journal of Agricultural and Food Research 34: 133-142.

Harris, S.L. and Clark, D.A. 1996. Effect of high rates of nitrogen fertiliser on white clover growth, morphology, and nitrogen fixation activity in grazed dairy pasture in northern New Zealand. New Zealand Journal of Agricultural Research 39: 149-158. 
Hetta, M., Cone, J.W., Gustavsson, A.M. and Martinsson, K. 2003. The effect of additives in silages of pure timothy and timothy mixed with red clover on chemical composition and in vitro rumen fermentation characteristics. Grass and Forage Science 58: 249-257.

Hopkins, A. 1986. Botanical composition of permanent grassland in England and Wales in relation to soil, environment and management factors. Grass and Forage Science 41: 237-246.

Hopkins, A., Gilbey, J., Dibb, C., Bowling, P.J. and Murray, P.J. 1990. Response of permanent and reseeded grassland to fertilizer nitrogen. 1. Herbage production and herbage quality. Grass and Forage Science 45: 43-55.

Keating, T. and O'Kiely, P. 2000a. Comparison of old permanent grassland, Lolium perenne and Lolium multiflorum swards grown for silage: 1. Effects on beef production per hectare. Irish Journal of Agricultural and Food Research 39: 1-24.

Keating, T. and O'Kiely, P. 2000b. Comparison of old permanent grassland, Lolium perenne and Lolium multiflorum swards grown for silage: 3 . Effects of varying fertiliser nitrogen application rate. Irish Journal of Agricultural and Food Research 39: 35-53.

King, C., McEniry, J., Richardson, M. and O'Kiely, P. 2012. Yield and chemical composition of five common grassland species in response to nitrogen fertililser. Acta Agriculturae Scandinavia 62: 644-658.

Li, G. and Kemp, P.D. 2005. Forage chicory (Cichorium intybus L.): a review of its agronomy and animal production. Advances in Agronomy 88: 187-222.

Lüscher, A., Finn, J.A., Connolly, J., Sebastià, M.T., Collins, R., Fothergill, M., Porqueddu, C., Brophy, C., Huguenin-Elie, O. and Kirwan, L. 2008. Benefits of sward diversity for agricultural grasslands. Biodiversity 9: 29-32.

Martin, K., Edwards, G., Bryant, R., Hodge, M., Moir, J., Chapman, D. and Cameron, K. 2017. Herbage dry-matter yield and nitrogen concentration of grass, legume and herb species grown at different nitrogen-fertiliser rates under irrigation. Animal Production Science 57: 1283-1288.

Michaud, A., Andueza, D., Picard, F., Plantureux, S. and Baumont, R. 2012. Seasonal dynamics of biomass production and herbage quality of three grasslands with contrasting functional compositions. Grass and Forage Science 67: 64-76.

Moloney, T., Sheridan, H., Grant, J., O'Riordan, E.G. and O'Kiely, P. 2020. Yield of binary- and multi-species swards relative to single-species swards in intensive silage systems. Irish Journal of Agricultural and Food Research 59: 12-26.

Moore, K., Moser, L.E., Vogel, K.P., Waller, S.S., Johnson, B. and Pedersen, J.F. 1991. Describing and quantifying growth stages of perennial forage grasses. Agronomy Journal 83: 1073-1077.
Nyfeler, D., Huguenin-Elie, O., Suter, M., Frossard, E., Connolly, J. and Lüscher, A. 2009. Strong mixture effects among four species in fertilized agricultural grassland led to persistent and consistent transgressive overyielding. Journal of Applied Ecology 46: 683-691.

Ohlsson, C. and Wedin, W.F. 1989. Phenological staging schemes for predicting red clover quality. Crop Science 29: 416-420.

Peyraud, J.L., Le Gall, A. and Lüscher, A. 2009. Potential food production from forage legume-based-systems in Europe: an overview. Irish Journal of Agricultural and Food Research 48 : 115-135.

Phelan, P., Moloney, A.P., McGeough, E.J., Humphreys, J., Bertilsson, J., O'Riordan, E.G. and O'Kiely, P. 2015. Forage legumes for grazing and conserving in ruminant production systems. Critical Reviews in Plant Sciences 34: 281-326.

Pirhofer-Walzl, K., Søegaard, K., Høgh-Jensen, H., Eriksen, J., Sanderson, M.A. and Rasmussen, J. 2011. Forage herbs improve mineral composition of grassland herbage. Grass and Forage Science 66: 415-423.

Sanderson, M.A. 2010. Nutritive value and herbage accumulation rates of pastures sown to grass, legume, and chicory mixtures. Agronomy Journal 102: 728-733.

Sanderson, M.A., Labreveux, M., Hall, M.H. and Elwinger, G.F. 2003. Nutritive value of chicory and English plantain forage. Crop Science 43: 1797-1804.

SAS. 2013. "SAS 9.4". SAS Institute Inc., Cary, NC, USA.

Temperton, V.M., Mwangi, P.N., Scherer-Lorenzen, M., Schmid, B. and Buchmann, N. 2007. Positive interactions between nitrogenfixing legumes and four different neighbouring species in a biodiversity experiment. Oecologia 151: 190-205.

Thomas, A. 1977. An automated procedure for the determination of soluble carbohydrates in herbage. Journal of the Science of Food and Agriculture 28: 639-642.

Thorvaldsson, G. and Andersson, S. 1986. Variations in timothy dry matter yield and nutritional value as affected by harvest date, nitrogen fertilization, year and location in northern Sweden. Acta Agriculturae Scandinavica 36: 367-385.

Tilley, J.M.A. and Terry, R.A. 1963. A two-stage technique for the in vitro digestion of forage crops. Journal of the British Grassland Society 18: 104-111.

Whitehead, D.C. 1995. "Grassland Nitrogen". CAB International, WIlingford, Oxfordshire, UK.

Wilman, D. 2004. Some changes in grass crops during periods of uninterrupted growth. The Journal of Agricultural Science 142: 129-140.

Wilson, R.K. and Collins, D.P. 1980. Chemical composition of silages made from different grass genera. Irish Journal of Agricultural Research 19: 75-84. 
Appendix Table A1: Mean growth stage indices for each herbage species from each sward species $\times$ inorganic $\mathrm{N}$ treatment at Cuts $1-3$ on the Early harvest schedule, averaged across years

\begin{tabular}{|c|c|c|c|c|c|c|c|c|c|c|c|c|c|c|c|c|c|c|c|c|c|}
\hline \multirow{2}{*}{$\begin{array}{l}\text { Species } \\
\text { Cut }\end{array}$} & \multicolumn{3}{|c|}{ PRG $^{1}$} & \multicolumn{3}{|c|}{ IRG $^{1}$} & \multicolumn{3}{|c|}{ TIM $^{1}$} & \multicolumn{3}{|c|}{$\mathrm{RC}^{2}$} & \multicolumn{3}{|c|}{ WC $^{3}$} & \multicolumn{3}{|c|}{ PLANT $^{3}$} & \multicolumn{3}{|c|}{$\mathrm{CHIC}^{3}$} \\
\hline & 1 & 2 & 3 & 1 & 2 & 3 & 1 & 2 & 3 & 1 & 2 & 3 & 1 & 2 & 3 & 1 & 2 & 3 & 1 & 2 & 3 \\
\hline $\mathrm{IRG} / 360 \mathrm{~N}$ & & & & 2.8 & 3.4 & 3.2 & & & & & & & & & & & & & & & \\
\hline TIM/360N & & & & & & & 2.4 & 3.1 & 2.4 & & & & & & & & & & & & \\
\hline $\mathrm{RC}$ & & & & & & & & & & 1.7 & 4.0 & 5.2 & & & & & & & & & \\
\hline IRG/RC & & & & 2.6 & 3.4 & 3.0 & & & & 1.7 & 3.0 & 5.0 & & & & & & & & & \\
\hline TIM/RC & & & & & & & 2.1 & 2.9 & 2.4 & 1.4 & 4.1 & 5.1 & & & & & & & & & \\
\hline PRG/RC & 2.3 & 2.7 & 1.6 & & & & & & & 1.9 & 4.4 & 5.4 & & & & & & & & & \\
\hline PRG/ON & 2.4 & 2.8 & 1.4 & & & & & & & & & & & & & & & & & & \\
\hline PRG/120N & 2.5 & 2.7 & 1.7 & & & & & & & & & & & & & & & & & & \\
\hline PRG/240N & 2.6 & 2.9 & 1.6 & & & & & & & & & & & & & & & & & & \\
\hline PRG/360N & 2.5 & 2.9 & 1.8 & & & & & & & & & & & & & & & & & & \\
\hline Mix $1 / 0 \mathrm{~N}$ & 2.3 & 2.9 & 1.7 & & & & 2.1 & 2.9 & 1.7 & 1.0 & 3.5 & 4.9 & 1.0 & 2.3 & 3.5 & & & & & & \\
\hline Mix $1 / 120 \mathrm{~N}$ & 2.4 & 2.8 & 1.8 & & & & 2.1 & 2.8 & 1.7 & 1.1 & 2.8 & 5.0 & 1.0 & 2.3 & 3.5 & & & & & & \\
\hline Mix $1 / 240 \mathrm{~N}$ & 2.3 & 2.9 & 1.7 & & & & 2.2 & 2.7 & 1.7 & 1.2 & 2.6 & 5.0 & 1.0 & 2.3 & 2.3 & & & & & & \\
\hline Mix $1 / 360 \mathrm{~N}$ & 2.4 & 3.1 & 1.5 & & & & 2.3 & 3.2 & 2.0 & 1.3 & 2.7 & 5.2 & 1.0 & 2.3 & 2.3 & & & & & & \\
\hline Mix $2 / 0 \mathrm{~N}$ & 2.3 & 2.8 & 1.8 & & & & 2.1 & 2.9 & 1.8 & 1.8 & 4.0 & 5.3 & & & & 2.0 & 4.0 & 4.0 & 1.5 & 2.5 & 2.5 \\
\hline $\operatorname{Mix} 2 / 120 \mathrm{~N}$ & 2.3 & 3.1 & 1.7 & & & & 2.2 & 3.0 & 1.7 & 1.8 & 3.8 & 5.2 & & & & 2.0 & 4.0 & 4.0 & 1.5 & 2.5 & 2.5 \\
\hline Mix $2 / 240 N$ & 2.4 & 3.1 & 1.8 & & & & 2.3 & 2.9 & 2.2 & 1.5 & 3.0 & 5.5 & & & & 2.0 & 4.0 & 3.8 & 1.5 & 3.3 & 2.0 \\
\hline Mix 2/360N & 2.4 & 3.2 & 1.9 & & & & 2.3 & 3.0 & 1.6 & 1.7 & 2.7 & 4.2 & & & & 2.0 & 3.5 & 4.0 & 1.5 & 3.0 & 1.5 \\
\hline
\end{tabular}

${ }^{1}$ Growth stage indices for perennial ryegrass (PRG), Italian ryegrass (IRG) and timothy (TIM) are from Moore et al. (1991).

${ }^{2}$ Indices for red clover (RC) are from Ohlsson and Wedin (1989).

${ }^{3}$ Indices for white clover (WC), ribwort plantain (PLANT) and chicory (CHIC) are from Table 2. 
Appendix Table A2: Mean growth stage indices for each herbage species from each sward species $\times$ inorganic $\mathrm{N}$ treatment at Cuts $1-3$ on the Late harvest schedule, averaged across years

\begin{tabular}{|c|c|c|c|c|c|c|c|c|c|c|c|c|c|c|c|c|c|c|c|c|c|}
\hline \multirow{2}{*}{$\begin{array}{l}\text { Species } \\
\text { Cut }\end{array}$} & \multicolumn{3}{|c|}{ PRG $^{1}$} & \multicolumn{3}{|c|}{ IRG $^{1}$} & \multicolumn{3}{|c|}{ TIM $^{1}$} & \multicolumn{3}{|c|}{$\mathrm{RC}^{2}$} & \multicolumn{3}{|c|}{ WC $^{3}$} & \multicolumn{3}{|c|}{ PLANT $^{3}$} & \multicolumn{3}{|c|}{$\mathrm{CHIC}^{3}$} \\
\hline & 1 & 2 & 3 & 1 & 2 & 3 & 1 & 2 & 3 & 1 & 2 & 3 & 1 & 2 & 3 & 1 & 2 & 3 & 1 & 2 & 3 \\
\hline IRG/360N & & & & 3.1 & 3.3 & 2.8 & & & & & & & & & & & & & & & \\
\hline TIM/360N & & & & & & & 3.0 & 3.0 & 2.5 & & & & & & & & & & & & \\
\hline $\mathrm{RC}$ & & & & & & & & & & 3.5 & 5.7 & 2.9 & & & & & & & & & \\
\hline IRG/RC & & & & 3.0 & 3.2 & 2.4 & & & & 2.9 & 5.8 & 3.7 & & & & & & & & & \\
\hline TIM/RC & & & & & & & 3.0 & 3.0 & 1.9 & 3.4 & 5.6 & 3.7 & & & & & & & & & \\
\hline PRG/RC & 3.0 & 2.8 & 1.6 & & & & & & & 3.5 & 5.9 & 3.7 & & & & & & & & & \\
\hline PRG/ON & 3.1 & 2.3 & 1.5 & & & & & & & & & & & & & & & & & & \\
\hline $\mathrm{PRG} / 120 \mathrm{~N}$ & 3.1 & 2.5 & 1.6 & & & & & & & & & & & & & & & & & & \\
\hline $\mathrm{PRG} / 240 \mathrm{~N}$ & 3.1 & 3.0 & 1.6 & & & & & & & & & & & & & & & & & & \\
\hline $\mathrm{PRG} / 360 \mathrm{~N}$ & 3.1 & 3.0 & 1.7 & & & & & & & & & & & & & & & & & & \\
\hline Mix $1 / 0 \mathrm{~N}$ & 3.1 & 2.6 & 1.5 & & & & 3.0 & 2.9 & 2.1 & 3.6 & 6.1 & 3.4 & 1.0 & 2.3 & 2.3 & & & & & & \\
\hline Mix $1 / 120 \mathrm{~N}$ & 3.1 & 2.9 & 1.8 & & & & 2.9 & 3.1 & 2.5 & 3.5 & 5.7 & 3.3 & 1.0 & 2.3 & 2.3 & & & & & & \\
\hline Mix $1 / 240 \mathrm{~N}$ & 3.0 & 2.8 & 1.9 & & & & 3.0 & 3.1 & 2.2 & 3.3 & 5.8 & 3.3 & 1.0 & 2.3 & 2.3 & & & & & & \\
\hline Mix $1 / 360 N$ & 3.1 & 2.8 & 1.9 & & & & 3.0 & 3.0 & 2.3 & 3.5 & 5.5 & 3.0 & 1.0 & 2.3 & 1.0 & & & & & & \\
\hline $\operatorname{Mix} 2 / 0 \mathrm{~N}$ & 3.1 & 2.6 & 1.8 & & & & 3.0 & 2.8 & 2.2 & 3.6 & 6.0 & 3.5 & & & & 3.8 & 4.3 & 2.3 & 2.8 & 2.8 & 1.0 \\
\hline Mix $2 / 120 N$ & 3.1 & 2.9 & 1.9 & & & & 3.0 & 3.0 & 2.7 & 3.3 & 5.9 & 3.3 & & & & 3.3 & 4.5 & 2.3 & 3.0 & 3.3 & 1.0 \\
\hline Mix $2 / 240 N$ & 3.1 & 2.8 & 1.9 & & & & 3.0 & 3.1 & 2.4 & 3.1 & 5.8 & 3.3 & & & & 4.0 & 4.5 & 2.0 & 2.8 & 3.0 & 1.5 \\
\hline Mix 2/360N & 3.1 & 3.0 & 1.9 & & & & 2.9 & 3.0 & 2.5 & 3.2 & 5.7 & 3.1 & & & & 4.0 & 4.5 & 2.5 & 3.3 & 2.0 & 1.0 \\
\hline
\end{tabular}

${ }^{1}$ Growth stage indices for perennial ryegrass (PRG), Italian ryegrass (IRG) and timothy (TIM) are from Moore et al. (1991).

${ }^{2}$ Indices for red clover (RC) are from Ohlsson and Wedin (1989).

${ }^{3}$ Indices for white clover (WC), ribwort plantain (PLANT) and chicory (CHIC) are from Table 2. 
Appendix Table A3: Mean dry matter (DM) content $(\mathrm{g} / \mathrm{kg})$ at each cut, for each harvest schedule and sward species $\times$ inorganic $\mathrm{N}$ treatment (averaged across years)

\begin{tabular}{|c|c|c|c|c|c|c|c|c|c|c|c|c|}
\hline Cut & & 1 & & & 2 & & & 3 & & & 4 & \\
\hline Schedule $^{1}$ & $E$ & $M$ & $\mathbf{L}$ & $E$ & $M$ & L & $E$ & $M$ & $\mathbf{L}$ & $E$ & $\mathbf{M}$ & $\mathbf{L}$ \\
\hline \multicolumn{13}{|l|}{ Sward $^{2}$} \\
\hline IRG/360N & 177 & 181 & 227 & 225 & 202 & 232 & 183 & 176 & 150 & 127 & 108 & 105 \\
\hline TIM/360N & 159 & 151 & 205 & 208 & 204 & 213 & 173 & 151 & 160 & 135 & 135 & 132 \\
\hline $\mathrm{RC}$ & 131 & 124 & 155 & 145 & 134 & 151 & 132 & 128 & 118 & 133 & 133 & 126 \\
\hline IRG/RC & 190 & 177 & 213 & 202 & 206 & 217 & 161 & 143 & 136 & 122 & 115 & 117 \\
\hline TIM/RC & 141 & 140 & 199 & 160 & 147 & 161 & 141 & 121 & 127 & 124 & 133 & 132 \\
\hline PRG/RC & 154 & 149 & 197 & 165 & 151 & 172 & 153 & 131 & 139 & 132 & 128 & 134 \\
\hline PRG/ON & 206 & 205 & 229 & 243 & 210 & 214 & 187 & 187 & 186 & 164 & 157 & 147 \\
\hline $\mathrm{PRG} / 120 \mathrm{~N}$ & 187 & 185 & 226 & 232 & 195 & 193 & 197 & 188 & 179 & 142 & 134 & 134 \\
\hline $\mathrm{PRG} / 240 \mathrm{~N}$ & 167 & 172 & 218 & 205 & 177 & 176 & 180 & 174 & 164 & 130 & 126 & 126 \\
\hline $\mathrm{PRG} / 360 \mathrm{~N}$ & 162 & 170 & 216 & 192 & 165 & 164 & 161 & 152 & 155 & 129 & 122 & 125 \\
\hline Mix $1 / 0 \mathrm{~N}$ & 156 & 145 & 197 & 168 & 152 & 177 & 144 & 127 & 130 & 122 & 119 & 126 \\
\hline Mix $1 / 120 \mathrm{~N}$ & 157 & 152 & 199 & 180 & 164 & 185 & 154 & 143 & 147 & 129 & 123 & 129 \\
\hline $\operatorname{Mix} 1 / 240 \mathrm{~N}$ & 151 & 152 & 212 & 184 & 170 & 182 & 159 & 151 & 157 & 145 & 121 & 127 \\
\hline Mix $1 / 360 \mathrm{~N}$ & 149 & 155 & 204 & 182 & 172 & 182 & 156 & 149 & 157 & 133 & 127 & 130 \\
\hline Mix $2 / 0 \mathrm{~N}$ & 150 & 140 & 195 & 159 & 148 & 172 & 144 & 123 & 124 & 118 & 114 & 109 \\
\hline $\operatorname{Mix} 2 / 120 \mathrm{~N}$ & 149 & 148 & 203 & 171 & 163 & 167 & 151 & 140 & 135 & 125 & 113 & 118 \\
\hline Mix $2 / 240 N$ & 146 & 150 & 204 & 170 & 161 & 188 & 148 & 142 & 154 & 119 & 124 & 128 \\
\hline Mix $2 / 360 N$ & 148 & 149 & 201 & 174 & 166 & 186 & 149 & 142 & 146 & 123 & 124 & 127 \\
\hline
\end{tabular}

${ }^{1}$ Harvest schedule: $\mathrm{E}=$ Early, $\mathrm{M}=$ Middle, $\mathrm{L}=$ Late.

${ }^{2}$ Sward species $\times$ inorganic $\mathrm{N}$ treatment.

Appendix Table A4: Standard errors of the mean (SEM) and $P$-values for dry matter (DM) content $(\mathrm{g} / \mathrm{kg})$ at each cut, for each harvest schedule and sward species $\times$ inorganic $\mathrm{N}$ treatment (averaged across years)

\begin{tabular}{|c|c|c|c|c|c|c|c|c|c|c|c|}
\hline \multirow{2}{*}{$\begin{array}{l}\text { Group }^{1} \\
\text { Effect }\end{array}$} & & \multicolumn{4}{|c|}{1} & \multicolumn{2}{|c|}{2} & \multicolumn{4}{|c|}{3} \\
\hline & & Species $^{2}$ & Source $^{2}$ & $\begin{array}{l}\text { Species } \\
\times \text { Source }\end{array}$ & $\begin{array}{c}\text { Species } \\
\times \text { Source } \\
\times \text { Schedule }\end{array}$ & Species $^{3}$ & $\begin{array}{c}\text { Species } \\
\times \text { Schedule }\end{array}$ & Species $^{4}$ & $\mathrm{~N}$ rate & $\begin{array}{l}\text { Species } \\
\times \mathrm{N} \text { rate }\end{array}$ & $\begin{array}{l}\text { Species } \\
\times \mathbf{N} \text { rate } \\
\times \text { Schedule }\end{array}$ \\
\hline \multirow[t]{2}{*}{ Cut 1} & SEM & 3 & 2.7 & 3.9 & 6.7 & 3.7 & 6.4 & 1.9 & 2.1 & 3.3 & 5.5 \\
\hline & $P$ & $<0.001$ & 0.001 & 0.085 & 0.243 & $<0.001$ & 0.279 & $<0.001$ & $<0.001$ & $<0.001$ & 0.855 \\
\hline \multirow[t]{2}{*}{ Cut 2} & SEM & 2.5 & 2.3 & 3.3 & 5.6 & 2.8 & 4.9 & 1.7 & 1.8 & 2.5 & 4.3 \\
\hline & $P$ & $<0.001$ & $<0.001$ & $<0.001$ & 0.005 & $<0.001$ & 0.001 & $<0.001$ & $<0.001$ & $<0.001$ & 0.191 \\
\hline \multirow[t]{2}{*}{ Cut 3} & SEM & 1.6 & 1.3 & 2.2 & 3.8 & 2.2 & 3.8 & 1.2 & 1.3 & 2.4 & 4 \\
\hline & $P$ & $<0.001$ & $<0.001$ & 0.001 & 0.18 & $<0.001$ & 0.087 & $<0.001$ & $<0.001$ & $<0.001$ & 0.138 \\
\hline \multirow[t]{2}{*}{ Cut 4} & SEM & 2.2 & 2 & 2.8 & 4.8 & 3.7 & 6.5 & 2.1 & 2.1 & 3.6 & 6.2 \\
\hline & $P$ & $<0.001$ & 0.253 & 0.059 & 0.877 & $<0.001$ & 0.702 & $<0.001$ & 0.548 & $<0.001$ & 0.742 \\
\hline
\end{tabular}

${ }^{1}$ Group $1=$ PRG/360N, IRG/360N, TIM/360N, PRG/RC, IRG/RC, TIM/RC and RC (the SEMs for Species were calculated for the $3 \times 2$ interaction but were also used when comparing RC to any of the $3 \times 2$ treatments); Group $2=\mathrm{PRG} / \mathrm{ON}, \mathrm{PRG} / \mathrm{RC}, \mathrm{Mix} 1 / \mathrm{ON}$ and Mix 2/0N; Group 3 = PRG/0-360N, Mix 1/0-360N and Mix 2/0-360N.

${ }^{2}$ Within Group 1, Species is IRG, PRG or TIM and Source is either grass $+360 \mathrm{~kg} \mathrm{~N} /$ ha per year or grass + red clover.

${ }^{3}$ Within Group 2, Species is PRG/0N, PRG/RC, Mix 1/0N and Mix 2/0N.

${ }^{4}$ Within Group 3, Species is PRG, Mix 1 and Mix 2. Schedule = Harvest schedule. 
Appendix Table A5: Mean ash content (g/kg dry matter) at Cuts 1-3, for each harvest schedule and sward species $\times$ inorganic $\mathrm{N}$ treatment (averaged across years)

\begin{tabular}{|c|c|c|c|c|c|c|c|c|c|}
\hline Cut & & 1 & & & 2 & & & 3 & \\
\hline Schedule $^{1}$ & $E$ & M & $\mathbf{L}$ & $E$ & $M$ & $L$ & $E$ & $M$ & $\mathbf{L}$ \\
\hline \multicolumn{10}{|l|}{ Sward } \\
\hline IRG/360N & 73 & 72 & 64 & 62 & 69 & 66 & 73 & 72 & 64 \\
\hline TIM/360N & 80 & 75 & 71 & 72 & 68 & 72 & 80 & 75 & 71 \\
\hline $\mathrm{RC}$ & 96 & 100 & 91 & 106 & 103 & 92 & 96 & 100 & 91 \\
\hline IRG/RC & 78 & 76 & 71 & 86 & 78 & 76 & 78 & 76 & 71 \\
\hline TIM/RC & 92 & 88 & 79 & 101 & 95 & 92 & 92 & 88 & 79 \\
\hline PRG/RC & 94 & 88 & 79 & 109 & 101 & 96 & 94 & 88 & 79 \\
\hline PRG/ON & 73 & 68 & 66 & 85 & 87 & 92 & 97 & 101 & 101 \\
\hline $\mathrm{PRG} / 120 \mathrm{~N}$ & 76 & 73 & 65 & 80 & 90 & 89 & 90 & 95 & 97 \\
\hline $\mathrm{PRG} / 240 \mathrm{~N}$ & 80 & 75 & 67 & 79 & 85 & 89 & 92 & 93 & 96 \\
\hline PRG/360N & 91 & 72 & 66 & 83 & 87 & 91 & 90 & 93 & 91 \\
\hline Mix $1 / 0 \mathrm{~N}$ & 90 & 89 & 77 & 98 & 98 & 93 & 98 & 105 & 104 \\
\hline Mix $1 / 120 \mathrm{~N}$ & 86 & 85 & 72 & 93 & 90 & 87 & 98 & 100 & 98 \\
\hline Mix $1 / 240 \mathrm{~N}$ & 87 & 84 & 66 & 88 & 86 & 81 & 91 & 96 & 89 \\
\hline Mix $1 / 360 \mathrm{~N}$ & 86 & 74 & 69 & 76 & 81 & 82 & 93 & 96 & 91 \\
\hline Mix $2 / 0 \mathrm{~N}$ & 96 & 89 & 79 & 107 & 103 & 101 & 105 & 112 & 114 \\
\hline Mix $2 / 120 \mathrm{~N}$ & 90 & 85 & 71 & 100 & 96 & 94 & 103 & 105 & 105 \\
\hline Mix $2 / 240 N$ & 91 & 81 & 69 & 94 & 89 & 84 & 99 & 98 & 93 \\
\hline Mix $2 / 360 N$ & 87 & 82 & 70 & 88 & 85 & 81 & 94 & 92 & 91 \\
\hline
\end{tabular}

${ }^{1}$ See footnotes beneath Appendix Table A3.

Appendix Table A6: Standard errors of the mean (SEM) and $P$-values for ash content ( $/ \mathrm{kg}$ dry matter) at Cuts $1-3$, for each harvest schedule and sward species $\times$ inorganic $\mathrm{N}$ treatment (averaged across years)

\begin{tabular}{|c|c|c|c|c|c|c|c|c|c|c|c|}
\hline \multirow{2}{*}{$\begin{array}{l}\text { Group }^{1} \\
\text { Effect }\end{array}$} & & \multicolumn{4}{|c|}{1} & \multicolumn{2}{|c|}{2} & \multicolumn{4}{|c|}{3} \\
\hline & & Species & Source & $\begin{array}{l}\text { Species } \\
\times \text { Source }\end{array}$ & $\begin{array}{c}\text { Species } \\
\times \text { Source } \\
\times \text { Schedule }\end{array}$ & Species & $\begin{array}{c}\text { Species } \\
\times \text { Schedule }\end{array}$ & Species & $\mathrm{N}$ rate & $\begin{array}{l}\text { Species } \\
\times N \text { rate }\end{array}$ & $\begin{array}{l}\text { Species } \\
\times N \text { rate } \\
\times \text { Schedule }\end{array}$ \\
\hline \multirow[t]{2}{*}{ Cut 1} & SEM & 1.6 & 1.5 & 2 & 3.7 & 1.6 & 2.8 & 1.4 & 1.5 & 1.9 & 3.3 \\
\hline & $P$ & $<0.001$ & $<0.001$ & 0.156 & 0.314 & $<0.001$ & 0.37 & $<0.001$ & 0.025 & $<0.001$ & 0.175 \\
\hline \multirow[t]{2}{*}{ Cut 2} & SEM & 1.2 & 1 & 1.5 & 2.6 & 1.2 & 2.1 & 1.3 & 1.4 & 1.9 & 3.2 \\
\hline & $P$ & $<0.001$ & $<0.001$ & $<0.001$ & 0.182 & $<0.001$ & $<0.001$ & $<0.001$ & $<0.001$ & $<0.001$ & 0.622 \\
\hline \multirow[t]{2}{*}{ Cut 3} & SEM & 0.9 & 0.8 & 1.2 & 1.4 & 1.2 & 2 & 0.8 & 0.8 & 1.2 & 2.1 \\
\hline & $P$ & $<0.001$ & $<0.001$ & $<0.001$ & 0.716 & $<0.001$ & 0.785 & $<0.001$ & $<0.001$ & $<0.001$ & 0.512 \\
\hline
\end{tabular}

${ }^{1}$ See footnotes beneath Appendix Table A4. 